\title{
Groundwater conceptual models: implications for evaluating diffuse pollution mitigation measures
}

\author{
D J Allen ${ }^{1}$, W G Darling ${ }^{1 *}$, J Davies ${ }^{1}$, A J Newell ${ }^{1}$, D C Gooddy ${ }^{1}$ and A L Collins ${ }^{2}$ \\ ${ }^{1}$ British Geological Survey, Maclean Building, Crowmarsh Gifford, Wallingford, OX10 8BB, UK \\ ${ }^{2}$ Rothamsted Research, North Wyke, Okehampton, Devon EX20 2SB \\ "Corresponding author (email: wgd@bgs.ac.uk)
}

\begin{abstract}
The Water Framework Directive (WFD) identifies diffuse pollution as a long-term threat to water quality. Farming contributes significantly to this pollution. There is a clear need for mitigation measures and assessment of their efficacy. Accordingly, Demonstration Test Catchments (DTCs) have been established in England to test the effectiveness of changes in agricultural practice on river water quality and ecology. However, the presence of groundwater in these hydrological systems implies a wide range of travel times for pollutants from source to receptor. Unless flow routes are better characterised, it will be difficult to gauge the success of control measures in the short-term. Using 3D modelling and supplementary hydrochemical information, this study considers the hydrogeology of several sub-catchments in the Avon DTC, southern England. Data suggest that groundwater ages $>25$ years exist in parts of the catchments; clearly observations like these must be used to judge the likely effectiveness of targeted control measures. The revealed hydrogeological complexity of the Avon catchment is unlikely to be unique, so the techniques described here should be applicable to other lowland river systems with moderate-to-high baseflow indices $(>0.5)$. To support the WFD, groundwater conceptual models should inform the design of effective measures for diffuse pollution mitigation.
\end{abstract}

\section{INTRODUCTION}

Agricultural land use and management can result in significant quantities of pollutants entering the aquatic environment. Phosphate, nitrate, pesticides, fine-grained sediment and faecal bacteria can significantly reduce the quality of water used for drinking, bathing, fishing and supporting aquatic biodiversity (e.g. Carpenter et al., 1998; Jarvie et al., 2005; Collins and Anthony 2008; Collins et al. 2011; Kay et al., 2008). Current European Union legislation in the form of the Water Framework Directive (WFD) and the associated daughter directives has led to a focusing of resources towards the issue of diffuse pollutants (2000/60/EC) with the target of achieving at least 'good status' in all water bodies by 2015 (although this may be 
delayed until 2027 provided certain conditions are satisfied). Although farming is not the sole cause of these problems, it is a significant contributor.

To mitigate the negative contributions from agriculture requires the use of specific control measures. These have included nitrate sensitive areas (Lord et al., 1999), nitrate vulnerable zones (Johnson et al., 2007) and more specific on-farm approaches (e.g. Zhang et al., 2012) . All of these measures have been implemented with the intention of reducing the impacts of diffuse pollution, while not having an unduly adverse effect on farm practices, productivity and profitability.

The effectiveness of these measures has been the source of some debate (Silgram et al., 2005; Worrall et al., 2009) but a need for the strategic management of diffuse pollution is inescapable (Lerner and Harris, 2009; Hewett et al., 2009; Krause et al., 2008). It is becoming increasingly clear that projecting the likely success of targeted on-farm measures, especially in the short-term, requires a holistic catchment-scale understanding of how potential pollutants travel from their primary sources to the receptor (e.g. river). Factors such as pathway, travel time, dilution and phase changes during the cascade from source to receptor all need consideration in order to understand, and ultimately to predict, the potential efficacy of a mitigation option or suite of measures and associated impacts on aquatic ecology.

For waterborne pollutants, it is essential to have an understanding of the surface and subsurface flow pathways between source and receptor, as the range of travel times for fast surface and slow subsurface flow routes can be large, ranging from the order of hours to possibly decades or longer. This variation in travel times has important implications for projecting the efficacy of targeted on-farm measures; for example, if fast surface routes are assumed but slow subsurface flows exist, a measure may be deemed to have failed in the short-term simply because the time to reach a receptor was increased by the pathways in operation. Knowledge of the water flow routes within a hydrological system or catchment can be incorporated into a hydrological conceptual model, in which understanding of the flow systems is derived from a range of information including physical, hydrochemical and geological data.

One approach to investigating the efficacy of mitigation measures is to use experimental catchments, where different control methods can be trialled and their effectiveness evaluated 
using a variety of procedures. In England, three experimental sentinel catchments, known as Demonstration Test Catchments (DTCs), have been established, funded by the Department for Environment, Food and Rural Affairs (DEFRA) (http://www.lwec.org.uk/activities/demonstrationtest-catchments).

The DTCs encompass a range of farming types, landscapes, rock types and relationships between surface and groundwaters. Within each of the DTCs, several sub-catchments have been selected and instrumented in order to investigate the links between targeted on-farm measures and their impacts on river chemistry and aquatic ecology. Monitoring data and additional lines of evidence including source apportionment will be used in a 'weight of evidence' approach to determine the efficacy of measures for reducing diffuse pollution at receptors. Long-term monitoring is expensive and therefore is rarely undertaken at more than a limited number of points within a catchment. Importantly, the monitoring data collected can only be correctly interpreted if the water flow routes are understood in detail. This limitation is especially significant for short-term (up to 5 years) studies which are the norm in terms of the catchment-based diffuse pollution work currently funded in most countries including the UK. Interpolation of this data is therefore crucial in assessing the longer term efficacy of any measures and their ability to contribute to diffuse pollution mitigation for WFD compliance.

Within this context, this paper presents preliminary groundwater conceptual models for the Hampshire Avon catchment DTC in southern England and discusses the potential implications of these models for the improved interpretation of surface water monitoring data. The conceptual models are based mainly on a review of existing data, with some new data obtained from limited targeted hydrochemical investigations. Owing to the relative paucity of geochemical and geophysical data, it is not possible to undertake an in-depth assessment of all catchment processes. However, it is considered that the conceptual models presented are accurate representations of the sub-catchments based on the best information available.

\section{BACKGROUND}

The Hampshire Avon catchment covers an area of $\sim 1700 \mathrm{~km}^{2}$ and drains part of southern Wiltshire including Salisbury Plain. The catchment encompasses solid geological units ranging in age from the Late Jurassic Kimmeridge Clay Formation to the Palaeogene Barton 
Group, although most of the catchment is underlain by Chalk. The Jurassic strata crop out in the west of the catchment, with the Palaeogene deposits occurring in the south.

The hydrogeology of the Avon catchment is dominated by the Chalk, the UK's principal aquifer. The Hampshire Avon and its tributaries generally have high base flow indices $(>0.7)$ indicating a large component of groundwater in their flow (Marsh and Hannaford, 2008). While the Chalk provides the main source of groundwater it has been recognised that the Upper Greensand also supports baseflow to rivers in the northern and western part of the Wessex Basin, including the Hampshire Avon (Soley et al., 2012).

The target sub-catchments, described below, are located in a number of geological settings in the western part of the Hampshire Avon DTC catchment (Figure 1). The focus of the present study has been the Upper Wylye sub-catchment, with the adjacent sub-catchments providing supporting evidence.

\subsection{The Upper River Wylye Sub-catchment}

\subsubsection{Setting and Geology}

Northernmost of the target sub-catchments, the Upper Wylye lies to the north of the Mere Fault in a large block of Cretaceous units including the Upper Greensand (UGS), Gault Clay and Chalk. The sub-catchment covers an area of $70 \mathrm{~km}^{2}$ upriver of the village of Hill Deverill (Figure 2). It consists of three distinct sections: a western system of wide, dry headwater valleys upriver of Kingston Deverill, a central intermittent winterbourne between Kingston and Brixton Deverill, and an eastern winterbourne between Brixton and Hill Deverill. The highest elevation in the sub-catchment is Long Knoll (288 m) with total variation in elevation of $\sim 160 \mathrm{~m}$.

The Upper Wylye sub-catchment is underlain predominantly by Chalk - ranging from the West Melbury Marly Chalk Formation at the base of the Chalk to the Seaford Chalk Formation - with a substantial outcrop of the UGS in the western area (Figure 3). The more open and elevated northern and western parts of the sub-catchment are underlain by the UGS. The remainder of the sub-catchment encompasses undulating Chalk downland into which the winterbourne section of the Upper Wylye valley and several dry tributaries have been incised. 
The West Melbury Marly Chalk is 25-40 m thick in the region (Bristow et al., 1999). The formation consists of soft marly chalk, sandy in the basal part and with some harder chalk beds. The overlying Zig Zag Chalk consists of 10-30 m of firm white chalk. Younger Chalk formations overlie the Zig Zag Chalk away from the valley bottom. The UGS comprises poorly-cemented to hard, massively-bedded well-cemented fine-grained glauconitic sands and sandstones which vary in thickness from about $30 \mathrm{~m}$ at Hill Deverill to around $70-75 \mathrm{~m}$ in the NW area (Bristow et al., 1999).

Superficial deposits of gravel and alluvium occur along the major rivers. On higher ground, outcrops of Upper Chalk are overlain by patches of clay-with-flints.

The structural geology of the area consists of series of secondary gentle E-W trending folds within a broad primary WNW-ESE trending anticline followed by the Wylye Valley. The underlying rock formations have a regional dip of $2-3^{\circ}$ to the ESE. Uplift and erosion have resulted in the incision of the River Wylye through the Upper Chalk along the main anticlinal structure.

\subsubsection{Hydrology}

The River Wylye sub-catchment receives an average rainfall of about $970 \mathrm{~mm} / \mathrm{a}$, mostly falling during winter and the early spring months, with an evaporation loss of about 460 mm/a (Avon and Dorset River Authority, 1973).

The hydrology of the Upper Wylye sub-catchment is complex. In the headwaters, to the west of Kingston Deverill (Figure 2), there are a small number of ephemeral spring sources which provide seasonal flow. Perennial springs feed the River Wylye upriver of Kingston Deverill and, under natural (unpumped) conditions, river flow historically continued downriver from Kingston Deverill during the winter months, with additional inputs from small springs at Brixton Deverill. However, historical records indicate that natural river flow declined downriver of Kingston Deverill during the summer months (e.g. Drayton, 1622) and, during prolonged dry periods and droughts, flow downriver of Monkton Deverill ceased altogether. The River Wylye flows continuously at Hill Deverill, where it is fed by large springs and shallow artesian boreholes. These spring and borehole flows are used to irrigate cress beds; with springflows occasionally failing during major droughts. 
Since 1974, summer season river flow has been augmented by groundwater pumped from river support boreholes located upriver of Kingston Deverill and Brixton Deverill. However, even the augmented flow may cease at Brixton Deverill village due to excessive river-bed leakage during drought years.

\subsubsection{Hydrogeological setting}

The UGS aquifer in the Upper Wylye sub-catchment is underlain by impermeable Gault Clay. Flow within the UGS varies from intergranular where unconsolidated, to fracture flow where cemented. The well-cemented low-permeability thinly-bedded malmstones of the Cann Sand Member of the UGS form occasional barriers to groundwater movement, sometimes giving rise to spring lines. The transmissivity of the UGS aquifer is considered to be around $300 \mathrm{~m}^{2} / \mathrm{d}$ (e.g Avon and Dorset River Authority, 1973).

The UGS is overlain by the Chalk aquifer, which can be highly productive, especially in valleys, as the result of fracturing. Valley transmissivities are commonly up to several thousands of metres squared per day, with low storativities (often less than 5\%) (Allen et al.,1997). While much of the Chalk sequence can be highly permeable where it is fractured, it is likely that the basal units of the Lower Chalk will be much less productive as a result of the presence of marls. Hydrogeological properties of the Avon DTC are shown in Table 1.

\subsection{The River Sem, Nadder and Ebble sub-catchments}

To the south of the Mere Fault (Figure 1) Jurassic strata, which underlie much of the Vale of Wardour, have been upwarped by Alpine compression to lie against Chalk to the north (Barton et al. 1998). The River Sem sub-catchment lies in relatively low-lying terrain, formed by a major incision in the outcrop of the Chalk. The northern parts of the River Sem catchment include steeply-dipping strata which form part of the Wardour Monocline, a linear zone of folding related to reverse movement on the concealed Mere Fault (Barton et al. 1998).

The River Sem is a tributary of the River Nadder, which flows eastward to join the River Wylye at Wilton, north-west of Salisbury and subsequently the River Avon at Salisbury. The two DTC target sub-catchments on the River Sem are located in the Cools Cottage and Priors Farm areas (Figure 1). 
The Cools Cottage sub-catchment of the River Sem has an area of $1.7 \mathrm{~km}^{2}$ above its outlet (Figure 4). This is the smallest of the Avon DTC target sub-catchments but, nevertheless, has a varied topography, with altitude rising by around $100 \mathrm{~m}$ between the catchment outlet and the highest point at Beacon Hill. The river rises from springs and then flows to the SW for around $1 \mathrm{~km}$ before meeting another tributary, downriver from Cools Cottage.

The Cools Cottage sub-catchment is underlain by geological units ranging in age from the Jurassic Kimmeridge Clay to the Cretaceous Lower Chalk (Figure 4). These units form a series of arcuate topographic benches increasing in elevation toward the NE. Strata dip toward the north, becoming steeply inclined in the northern part of the catchment as they approach the Wardour Monocline. The Kimmeridge Clay forms the low-lying SW part of the catchment and is overlain by sandstones and limestones of the Wardour Formation and Portland Limestone. The overlying Gault Clay, with locally preserved Lower Greensand at the base, is capped by the UGS, which includes the Cann Sand, Shaftesbury Sandstone and Boyne Hollow Chert members, which crop out as a prominent escarpment. The UGS is overlain in the NW part of the catchment by a small area of steeply-dipping Lower Chalk.

The Cools Cottage sub-catchment is underlain by both aquifer and non-aquifer material. The sub-catchment broadly slopes down from NE to SW, trending from younger to older strata (Figure 4). The UGS forms an aquifer outcropping in the northern, topographically highest, part of the sub-catchment. Below this, and to the SW, a layer of low permeability Gault Clay runs across the sub-catchment, hydraulically separating the UGS from the underlying Portland Group. The Portland Group outcrop consists of the Portland Stone Formation underlain by the Wardour Formation, with springs emerging from the latter, indicating some aquifer potential. Further to the SW, the sub-catchment is underlain by impermeable Kimmeridge Clay, normally considered to be a non-aquifer. However, here evidence from boreholes suggests that limited groundwater does occur, associated with thin interbedded limestones within the formation. Whether these have any bearing on groundwater discharge to the river is at present unknown.

The Priors Farm sub-catchment of the River Sem has an area of $\sim 5 \mathrm{~km}^{2}$. Flow occurs broadly from west to east across the sub-catchment, which has little topographic variation (around 30 $\mathrm{m})$. The sub-catchment is underlain almost entirely by mudstones and calcareous mudstones of the Kimmeridge Clay Formation (Figure 5) with very small areas of Gault Clay and UGS 
forming escarpments along the northern and southern boundaries of the sub-catchment. The Kimmeridge Clay includes several thick limestone beds, one of which crops out as an escarpment along the western boundary of the sub-catchment. This limestone bed dips to the east of the escarpment. There are local deposits of head and alluvium, the latter being confined to the stream valleys. The hydrology of the catchment is dominated by the underlying impermeable Kimmeridge Clay, with surface runoff predominating. The waterbearing limestones within the Kimmeridge Clay may contribute some groundwater to the river, although quantities are likely to be small.

The Rivers Nadder and Ebble sub-catchments are located to the south of the Vale of Wardour (Figure 1) upon a block of southerly-dipping Cretaceous strata. The River Nadder is primarily underlain by UGS while the River Ebble is mostly underlain by Chalk.

The River Nadder rises from perennial springs at Wincome Park to flow eastward towards the sub-catchment outlet at Donhead St Mary (Figure 6). The Nadder valley is relatively steepsided with a significant altitude variation of $\sim 120 \mathrm{~m}$ within a catchment area of $4.3 \mathrm{~km}^{2}$.

The River Nadder sub-catchment is underlain by impermeable Gault Clay and permeable UGS (Figure 6) that dip at $1^{\circ}-2^{\circ}$ to the SE. The Gault Clay, below the valley floor, is overlain by the UGS which forms steep valley sides. Here the UGS comprises the finegrained Cann Sand, sands and sandstones of the Shaftesbury Sandstone and the locallycemented sandstones of the Boyne Hollow Chert that cap the plateau forming the boundary of the sub-catchment.

The River Ebble sub-catchment at Ebbesbourne Wake is the most easterly of the Avon DTC target sub-catchments, lying to the east of the River Nadder. The sub-catchment, with an area of $8.5 \mathrm{~km}^{2}$ forms an ephemeral winterbourne upriver of Ebbesbourne Wake (Figure 7). The river dries up during the summer over its entire length in the sub-catchment and downriver for another $4.5 \mathrm{~km}$ as far as the perennial springs at Broadchalke. The river in the subcatchment is monitored upriver and downriver of an artificial wetland at Ebbesbourne Wake.

The River Ebble sub-catchment is underlain by formations of the Chalk Group (Figure 7); with West Melbury Marly Chalk underlying the valley bottom and Zig Zag Chalk to Seaford Chalk cropping out along the steep valley sides. These Chalk formations have dips of up to $3^{\circ}$ 
within an eastward-plunging synclinal fold, the axis of which is broadly coincident with the river's course. The relatively soft and clay-rich West Melbury Marly Chalk forms low-relief terrain on the floor of the catchment and underlies most of the river valley. Overlying harder chalks of the Zig Zag Chalk, Holywell Chalk and New Pit Chalk form a steep escarpment capped by a sinuous, dissected plateau of Lewes Nodular Chalk locally overlain by flint-rich Seaford Chalk. Limited local superficial deposits of head and of river alluvium are also present.

\section{METHODS}

The starting point for the development of conceptual models of the Hampshire Avon DTC target sub-catchments was the catchment geology, which provided the framework for the aquifers and the context for groundwater flow systems. Datasets of bedrock and superficial deposit geology at 1:50 000 scale held by the British Geological Survey (BGS) were used to produce $3 \mathrm{D}$ geological block models using $\mathrm{GOCAD}^{\mathrm{TM}}$. The likely aquifer characteristics of the different units used in the models were derived from published and unpublished literature. Borehole data (depth, geology penetrated, water levels, yields) were obtained from the National Well Archive held by BGS. Spring locations and other surface water features were obtained from 1:10,000 Ordnance Survey maps and flow accretion data were provided by Wessex Water Plc. Field visits enabled recognition of spring type and water source locations to be identified and provided opportunity for anecdotal evidence to be collected.

The initial conceptual models were further developed on the basis of results obtained from additional hydrochemical investigations. Water samples from springs, boreholes and river courses, mainly from the Upper River Wylye sub-catchment, were obtained for hydrochemical analysis during February and May 2012. Groundwater samples were generally collected using a submersible pump following purging until $\mathrm{pH}$, alkalinity, redox potential, dissolved oxygen and specific electrical conductivity stabilised. Samples for inorganic chemical analysis were passed through a $0.45 \mu \mathrm{m}$ filter, with an aliquot of the filtered sample being acidified $(1 \% \mathrm{v} / \mathrm{v})$ with nitric acid for cation analysis. Isotope samples were collected unfiltered. $\mathrm{CFC}$ and $\mathrm{SF}_{6}$ samples were collected free from atmospheric contamination according to the method of Oster (1994). Fluorescence samples were passed through a $0.45 \mu \mathrm{m}$ silver filter and stored in $10 \mathrm{~mL}$ glass vials with foil- lined caps. 
Inorganic chemistry was determined by ion chromatography for anions, and inductively coupled plasma - optical emission spectroscopy (ICP-OES) for cations. Oxygen, hydrogen and carbon stable isotopes were measured by isotope ratio mass spectrometry following preparation by equilibration with $\mathrm{CO}_{2}\left(\delta^{18} \mathrm{O}\right)$, zinc reduction $\left(\delta^{2} \mathrm{H}\right)$ and acidification $\left(\delta^{13} \mathrm{C}\right.$ $\mathrm{DIC})$. $\mathrm{CFC}$ and $\mathrm{SF}_{6}$ concentrations were measured by gas chromatography using cryogenic pre-concentration and an electron capture detector (ECD) based on the method in IAEA (2006). Fluorescence was analysed by spectrometry (method details in Lapworth et al., 2008).

\section{CONCEPTUAL MODEL OF THE UPPER RIVER WYLYE SUB-CATCHMENT}

\subsection{Physical hydrogeology}

The hydraulic relationship between the UGS and the Chalk in the Upper River Wylye catchment is not fully understood. The two aquifers are often treated as a single unit, with production boreholes completed in both. However, a number of factors suggest that the UGS is essentially confined, with minimal leakage from the Chalk. Firstly, where known, the potentiometric surface in the UGS is commonly above that of the overlying Chalk (particularly in the eastern part of the sub-catchment). Secondly, the marly nature of the West Melbury Marly Chalk imparts low permeability to this formation. Thirdly, artesian boreholes in the UGS, and the presence of significant springs where the Chalk thins to the east, strongly suggest that the UGS is essentially confined where overlain by the Lower Chalk.

The complex behaviour of the River Wylye can be largely explained on the basis of the hydrogeological behaviour of the two underlying aquifers, the UGS and the Chalk. Given the likely confined (or at least semi-confined) nature of the UGS, the two aquifers are considered separately.

The western headwaters of the River Wylye are underlain by UGS where, in response to winter recharge, elevated potentiometric levels in the aquifer give rise to a series of seasonal springs and issues (Figure 8). These springs dry during the summer as groundwater levels fall. Groundwater in the aquifer flows downdip to the SE to a point where the unconfined UGS aquifer passes beneath, and becomes confined by, poorly permeable marl and clay units of the West Melbury Marly Chalk. The potentiometric head within the confined UGS aquifer then becomes increasingly artesian along the valley bottom to the east, reaching its maximum in the vicinity of Hill Deverill (Figure 8). As the marly Chalk thins to the east, leakage 
resulting from this artesian head results in a substantial UGS water contribution to the perennial flows from springs and the wells at, and downriver from, Hill Deverill.

The perennial springs at Kingston Deverill that feed the headwaters of the River Wylye rise from Chalk, but are located near to the western outcrop of the UGS. Given that a fracture zone may exist in this area, the possibility exists that the springs may be fed by an UGS or mixed UGS/Chalk source.

Between Kingston Deverill and the main UGS discharges at Hill Deverill and beyond, natural river flows are controlled by the Chalk aquifer where it outcrops in the river valley. From the vicinity of Kingston Deverill downriver the River Wylye may have been incised along a fracture-controlled SW-NE trending valley where the river flows over a shallow basin of Lower Chalk strata (Figure 9). In the same sector the valley sides are formed of Upper and Middle Chalk units. Within this basin, Chalk groundwater is contained within the permeable Zig Zag Chalk Formation, with little storage in the underlying basal West Melbury Marly Chalk Formation. Any groundwater flow along the valley within the Lower Chalk is likely to take place preferentially within the near surface component of the Zig Zag Chalk, where subkarstic weathering probably occurs. High transmissivities approaching $9000 \mathrm{~m}^{2} / \mathrm{d}$ have been calculated (Avon and Dorset River Authority, 1973) in association with flint bands and gravels.

The high permeability of the Zig Zag Chalk may explain why the river flow sinks underground during the summer months, when water levels are depressed. In contrast, during the wetter winter months, rapid runoff of rainfall flows down into the valley effectively filling the chalk basin resulting in high rates of surface flow. This state continues to persist, but at a reducing rate, during the spring when rainwater that has infiltrated into the Middle and Upper Chalk units seeps out along the valley sides to maintain river flow.

The natural flow regime of the Upper River Wylye is modified by the seasonal pumping of groundwater to augment river flow during dry periods and by water abstraction for public and private supply. Some of this water will be recycled to the river after use, and the river augmentation scheme in particular significantly affects river flows downriver. The augmentation water is sourced from both the Chalk and underlying UGS aquifers. River flows supported by this water then tend to decrease downriver as water is lost to the river bed 
and underlying Chalk and therefore the effectiveness of augmentation is dependent on the permeability of the river bed and its hydraulic continuity with the underlying (possibly subkarstic) Chalk aquifer. The UGS aquifer is confined by the clayey portion of the West Melbury Marly Chalk, thus limiting recycling of augmentation water through the Chalk aquifer into the UGS aquifer.

\subsection{Hydrochemistry}

\subsubsection{Hydrochemical results}

Sampling site details are summarised in Table 2 and their locations in the Upper River Wylye sub-catchment are shown in Figure 10. Results for both the Rivers Wylye and Sem are divided into inorganic hydrochemistry (Table 3), stable isotopes (Table 4), CFCs and $\mathrm{SF}_{6}$ (Table 4) and fluorescence (Table 4).

Inorganic hydrochemistry. Samples from the Upper River Wylye sub-catchment (sites 3-10) are basically $\mathrm{Ca}-\mathrm{HCO}_{3}$ waters with only subsidiary amounts of other anions and cations, and typical of groundwaters which have interacted with the Chalk (e.g. Darling et al., 2012b). Nitrate, while elevated, is below the statutory limit for drinking water of $11.3 \mathrm{mg} / \mathrm{L}$ (as $\mathrm{NO}_{3}$ $\mathrm{N})$. Total $\mathrm{P}$ is very variable, ranging from 21 to $301 \mu \mathrm{g} / \mathrm{L}$. Samples from the River Sem $(1,2)$ are also $\mathrm{Ca}-\mathrm{HCO}_{3}$ waters, but $\mathrm{Mg}$ and $\mathrm{Na}$ are higher than in the River Wylye, while $\mathrm{Sr}$ is lower, reflecting the predominantly non-carbonate rocks of this sub-catchment.

Stable isotopes. Stable $\mathrm{O}$ and $\mathrm{H}$ isotopes vary little beyond measurement precision $( \pm 0.1 \%$ and $\pm 1 \%$ respectively). These results are typical of the isotope ratios to be expected for modern or near-modern groundwaters in this area. (Darling et al., 2003), indicating that all the groundwaters are the product of normal processes of infiltration. Carbon stable isotopes vary well beyond the method precision $( \pm 0.2 \%)$. Typically waters issuing from the unconfined Chalk aquifer have $\delta^{13} \mathrm{C}$-DIC values in the range -13 to $-16 \%$ (e.g. Darling et al., $2012 \mathrm{~b}$ ), with more negative values suggesting the addition of $\mathrm{CO}_{2}$ from the oxidation of organic material.

CFCs and $\mathrm{SF}_{6}$. The use of $\mathrm{CFCs}_{\text {and }} \mathrm{SF}_{6}$ as sensitive environmental tracers in groundwater investigations is outlined in Darling et al. (2012a). All CFC-11 concentrations are abovemodern, indicating a pervasive small pollution-related enhancement typical of many 
groundwaters in southern England (Darling et al., 2012b). While a small amount of CFC-12 contamination cannot be ruled out, only two of the samples have slightly above-modern concentrations. All $\mathrm{SF}_{6}$ concentrations were below modern, meaning that they could be used with some confidence as groundwater age tracers.

Fluorescence. Fluorescence is a sensitive way of detecting and characterising dissolved organic matter (DOM) (Lapworth et al., 2008). Groundwater DOM can conveniently be divided into 'fulvic acid-like' and 'tryptophan-like' fractions, effectively equivalent to organic matter derived from soil and living matter sources, respectively. The measured activities for the tryptophan-like fraction show that with the exception of one site, all the waters have evidence of inputs containing human or animal-derived DOM.

\subsubsection{Hydrochemical interpretation}

Relative proportions of Upper Greensand and Chalk groundwater. The hydrochemistry of UGS water is characterised by elevated amounts of $\mathrm{Si}$ and $\mathrm{Mg}$. Figure 11 is a plot of $\mathrm{Si}$ vs $\mathrm{Mg} / \mathrm{Ca}$ (to normalise $\mathrm{Mg}$ in the carbonate system) which shows mixing between UGS water as produced from the Eastern BH (site 5) and a Chalk end-member as defined by the mean of the composition of the Kingston Deverill large spring (site 8), the Kingston Deverill well (site 9) and the Hill Deverill spring (site 6).

On this basis the River Wylye at Kingston Deverill (site 10) at the time of sampling had a low proportion of UGS water, while the Kingston Deverill small spring ( site 7), the Central BH (site 4 ) and the Eastern BH (site 3 ) each had $>50 \%$ of UGS water.

The hydrochemical distinction between UGS and Chalk-derived water enables the conceptual model to be refined. The data indicate that at Kingston Deverill, the water from the Kingston Deverill large spring (site 8) and Kingston Deverill well (site 9) is essentially derived from the Chalk. The river Wylye (site 10), which at the time of sampling rose on West Melbury Marly Chalk to the west of Kingston Deverill, was mainly composed of Chalk water with a small UGS signature, while the Kingston Deverill small spring (site 7) indicated a greater proportion of UGS water. Thus, most of the discharge supporting the River Wylye at Kingston Deverill is derived from the Chalk, with limited local inputs of UGS water, perhaps flowing via local fracture systems, and therefore water in the deeper UGS aquifer appears to 
be flowing down the valley beneath the Chalk with limited upward leakage. The catchment area for the springs at Kingston Deverill is therefore mainly within the Chalk outcrop and, if the groundwater catchment is broadly coincident with the surface water catchment, suggests that a significant spring such as the Kingston Deverill large spring (site 8) derives its water from the Chalk valley to the south-west.

Mixed UGS/Chalk water was found in the Central BH (site 4); the borehole is known to be completed in both aquifers. The mixed water found at the Western BH (site 3), is however unexpected since the borehole is completed in Chalk. However the base of this borehole is likely to be close to the Chalk/UGS junction which may explain the mixing of these sources.

At the eastern end of the River Wylye sub-catchment, at Hill Deverill, the UGS hydrochemical signature found in the Eastern $\mathrm{BH}$ (site 5) is expected since the borehole abstracts only from that formation, which is confined beneath the Chalk. The nearby Hill Deverill spring (site 6) has a Chalk signature, clearly indicating its origin in the West Melbury Chalk, or a higher Chalk formation.

Residence times. The occurrence of minor CFC-12 enhancement at two sites (3 and 9) has been noted earlier. Taking the other CFC-12 results at face value and plotting against $\mathrm{SF}_{6}$ (Figure 12), the following conclusions can be drawn. The oldest waters are from the Eastern $\mathrm{BH}$ and the Kingston Deverill large spring (site 8) (i.e. the mixing end-members from Figure 11), and appear to be from systems exhibiting exponential piston flow (EPM), i.e. basically piston flow but with an exponential spread of flowpaths. In terms of mean residence time, ages of $\sim 25$ years are indicated. The Hill Deverill spring (site 6) is similarly from an EPM system, but with an age of $\sim 15$ years. The Central BH (site 4) is closer to an exponential mixing model (EMM), with a mean residence time of $\sim 25$ years.

Although not shown, the ratio $\mathrm{Mg} / \mathrm{Ca}$ proves to have no relationship with $\mathrm{SF}_{6}$ age and is therefore not predominantly a consequence of incongruent carbonate dissolution, meaning that it can be used as a mixing indicator, as shown in Figure 11.

An age of $\sim 25$ years for the Chalk Kingston Deverill large spring (site 8) is consistent with an extended recharge source in the Chalk catchment area to the south-west. However, a similar age for the UGS water at the Eastern BH (site 5) is very young if the water was entirely 
derived from the western outcrop of the UGS upriver of Kingston Deverill and had travelled along the valley under the Chalk as suggested by Figure 8. Given the implied velocity (200 $\mathrm{m} / \mathrm{yr}$ if a distance of $5 \mathrm{~km}$ is assumed) and the head gradient $(0.003 \mathrm{~m} / \mathrm{m})$ this would indicate a hydraulic conductivity of $\sim 180 \mathrm{~m} / \mathrm{d}$ which is unrealistically high for the UGS. It is very likely therefore that an additional, more local source(s) of recharge to the UGS is involved, perhaps laterally from the Chalk (it is not known with any certainty to what extent the water from the Eastern BH (site 5) represents the UGS baseline, so some dilution by Chalk groundwater could be occurring). To illustrate the residence-time concept, Figure 13 shows the cross-section from Figure 9 with age information added.

Nutrients. The evidence with regard to nitrogen and phosphorus is consistent with both the previous sections on groundwater mixing and age. A plot of $\mathrm{NO}_{3}-\mathrm{N}$ vs $\mathrm{P}$ (Figure 14) reveals what appears to be mixing between a relatively high-P, low-N water from the UGS as found at the Eastern $\mathrm{BH}(5)$ and a relatively low-P, high-N water as found at the Kingston Deverill large spring (site 8). It is assumed that the P in the UGS is of natural origin (the occurrence of phosphate in the Wessex UGS was considered by Tresise, 1960). Two major departures from this trend are the samples from the Western BH (site 3) and Kingston Deverill small spring (site 7), the implication being that $\mathrm{P}$ has been added to the local groundwater by farming activities. The Kingston Deverill well (site 9) is affected to a lesser degree. It is already apparent from Figure 12 that the Western BH (site 3) and the Kingston Deverill well (site 9) had slightly over-modern CFC-12, which would be consistent with anthropogenic inputs associated with farming (the Kingston Deverill small spring (site 7) had too small a discharge to be sampled for $\mathrm{CFCs}$ and $\mathrm{SF}_{6}$ ). These three sites also have the highest tryptophan-like fluorescence activities (Table 4), indicative of animal waste contributions (Lapworth et al., 2008) and mixed farming is present in this sub-catchment. Further evidence comes from the $\delta^{13} \mathrm{C}$-DIC values for sites 3 and 7, which are depleted compared to baseline values (Table 4), probably owing to the oxidation of organic matter.

\section{PRELIMINARY GROUNDWATER CONCEPTUAL MODELS OF THE SEM, NADDER AND EBBLE SUB-CATCHMENTS}

Of the two River Sem sub-catchments, the Cools Cottage study area has a more varied geology than that of Priors Farm: only 19\% of the catchment is underlain by Kimmeridge Clay (and a further $16 \%$ underlain by Gault Clay), and there is a significant area of aquifer 
outcrop, comprising UGS/Portland Limestone and Wardour Formation. This results in the river draining the Cools Cottage sub-catchment having substantial spring support, particularly from the Wardour Formation (and overlying Portland Stone).

A conceptualisation of the hydrogeological functioning of the River Sem above Cools Cottage is shown in Figure 15. The river appears to rise principally from springs draining the Jurassic Wardour Formation, (and presumably the overlying Portland Stone Formation) near to its junction with the underlying Kimmeridge Clay (Figures 5 and 15). Any more-elevated springs draining the UGS (as shown on Figure 14) do not appear to contribute directly to river flow. From its spring source, the River Sem runs over the Kimmeridge Clay Formation to Cools Cottage; further minor groundwater inputs may derive from issues in the Kimmeridge Clay or from other minor Wardour Formation sources.

As part of this study, the main spring forming the headwaters of the river (issuing from the base of the Wardour Formation in Figure 15) was sampled as was the river at the subcatchment outlet (Sites 1 and 2, Table 2) and the results are shown in Tables 2-4. On the basis of the $\mathrm{CFC}_{-\mathrm{SF}_{6}}$ plot (Figure 12), the Cools spring yields a mixed water which is about $60 \%$ modern. Table 3 shows that the Cools Cottage samples tend to be more mineralised in $\mathrm{Mg}, \mathrm{Na}$ and $\mathrm{Cl}$, but less mineralised in $\mathrm{Ca}, \mathrm{Si}, \mathrm{Sr}$ and $\mathrm{P}$ compared to the UGS in the Upper Wylye. It is therefore unlikely that the UGS is contributing significantly to this water.

Table 3 shows that $\mathrm{NO}_{3}-\mathrm{N}$ concentrations are lower than in the Chalk of the Upper Wylye sub-catchment, but that $\mathrm{P}$ at $50 \mathrm{ug} / \mathrm{L}$ is rather higher than the Chalk baseline values and is possibly derived from a geological source.

In the River Sem Priors Farm sub-catchment, the impermeable nature of the Kimmeridge Clay underlying nearly all of the sub-catchment indicates that groundwater is unlikely to be an important contributor to river flow, although the presence of limestone beds suggests that some groundwater flow is possible.

In the River Nadder sub-catchment, the river rises from springs at the base of the permeable UGS where it meets the underlying impermeable Gault Clay (Figure 16), although the exact spring locations are controlled by overlying low-permeability head deposits. Springs also occur at this junction outside the sub-catchment to the west. The UGS-fed river then flows 
eastwards to the sub-catchment outlet along a valley underlain by Gault Clay. The river flow is enhanced along its course by discharges from a number of springs and issues which also originate mainly at the UGS/Gault Clay junction.

The River Ebble is a winterbourne and is essentially groundwater-fed, with the perennial head located downriver of the DTC sub-catchment, at Broadchalke. The winterbourne behaviour is unusual with the river wetting and drying annually rapidly along the whole of the reach (over a period of only 1-2 weeks). There are no significant springs, there being only a minor source at the river head at Berwick St John. Examination of regional groundwater gradient data suggests that the water table has a similar gradient and direction to that of the valley floor (Figure 17), therefore when the water table rises it rapidly intersects the river bed over a significant distance, causing flow to commence over a long reach. Similarly, flow ceases rapidly over a significant distance as the water table falls to the river bed.

\section{DISCUSSION}

\subsection{The significance of conceptual groundwater models for evaluating the effects of diffuse pollution mitigation}

\subsubsection{Upper River Wylye}

In the Upper River Wylye, the river chemistry is monitored at the outlets of the western and central sub-catchments (Figure 18). In the future, assuming that funding becomes available for targeted interventions, the ongoing baseline hydrochemical monitoring potentially provides an opportunity to observe the effects of diffuse pollution mitigation measures employed in the central catchment by comparing the water chemistry at the two monitoring points, as the central sub-catchment monitoring station also includes water from the upper, western, catchment. However, this monitoring strategy assumes that the western, central and eastern catchments act hydraulically as separate sub-units, and, given that most of the river water is supplied from groundwater, it assumes that water infiltrating into the western subcatchment will emerge upriver of the western catchment monitoring station and that the same is true for the central sub-catchment monitoring station. It also assumes that groundwater catchment geometry is similar to that of the surface water catchment. As discussed above, however, the Upper River Wylye sub-catchment is complex hydraulically and these simple assumptions therefore need to be considered carefully, both in the interpretation of the 
baseline data being collected at present, and in conjunction with the planning of any additional mitigation measures in the future.

As an example, some water recharging the western sub-catchment passes underneath the central sub-catchment through the underlying UGS aquifer and re-emerges downriver, at the eastern end of the eastern sub-catchment, or further downriver. Such water is not sampled by the western monitoring station, but as it by-passes the central monitoring station also, it does not invalidate the method of using chemical differences between the monitoring stations. However, any water from the UGS entering the river between the monitoring stations will presumably have originated in the western sub-catchment, by-passing the western monitoring station and thus questions the basic assumptions of the comparative method for hydrochemical data strings. In this context, an important question is the origin of the substantial flow gain to the river downriver from the western monitoring station. The work carried out to date suggests that this originates mainly from the Chalk within the central subcatchment and may predominantly flow from an area situated to the south-west. If so, then any future measures implemented in this area are likely to have a disproportionate effect on river chemistry. As an example, this demonstrates the need to take account of subsurface flow pathways in the targeting of on-farm measures, as opposed to simply the more obvious surface delivery pathways from source to receptor.

A third potentially complicating issue is the impact of the river augmentation boreholes. The western augmentation borehole is situated between the two existing monitoring stations (Figure 18) and will thus affect river flow quantity and presumably chemistry, between the two. The source of its water is both the Chalk and the UGS and, given its proximity to the monitoring station, much of the water delivered downriver of the station will originate upriver (i.e. will by-pass the monitoring station). While the Eastern $\mathrm{BH}$ is downriver of the eastern DTC monitoring station and will thus nominally have no effect on the hydrochemistry results, its local drawdown may affect upriver flows. There is evidence that UGS water in the sub-catchment is naturally high in $\mathrm{P}$ and this may affect river monitoring results, as will the fact that the boreholes are pumped intermittently. Borehole source impacts therefore need to be taken into consideration during the interpretation of river chemistry in those areas in receipt of river augmentation. 


\subsubsection{Rivers Sem, Nadder and Ebble}

Given that the two River Sem sub-catchments are geographically similar it might be assumed that they would respond hydrologically in a similar way and would therefore readily lend themselves to a paired sub-catchment comparative approach. However, as has been shown, the hydraulic functioning of the catchments is likely to differ and this may well have an important bearing on the interpretation of the results of hydrochemical monitoring.

The Priors Farm sub-catchment of the River Sem is underlain almost entirely by Kimmeridge Clay and this is likely to have a dominating effect on the baseline chemistry of any groundwater component of flow. The Kimmeridge Clay has poor aquifer properties and therefore it might be expected that the river will be mainly supported by surface runoff and therefore likely to be 'flashy' with peaky hydrographs. However there are indications of some groundwater contribution to river flow; the river does appear to flow in dry periods (albeit at a low discharge) and limestone beds which may be water-bearing are present within the clay (and may provide the source of supply for a water borehole in the catchment).

By contrast, river flow in the Cools Cottage sub-catchment of the River Sem includes both spring sources and surface runoff so that the relationship between land use and river chemistry is likely to be more complex. Were measures to be applied to land underlain by Kimmeridge Clay, their effect would probably become apparent in the chemistry of the river in a short time span. However the upriver springwaters, which appear to contribute a significant proportion of river flow in the Cools Cottage sub-catchment, will have longer residence times than surface runoff, implying a greater delay between land use activities and their effect on river flow chemistry. In addition, the relationship between the location of different land use and the recharge areas of the springs will determine whether the spring chemistry will show the effects of any inappropriate farming practices or cropping such as those requiring higher nutrient inputs. Finally, the baseline chemistries of monitored water in the two River Sem sub-catchments may be different, both as a result of the different flow mechanisms and because of the varying mineralogy of the underlying material. All of these factors need to be considered carefully during the interpretation of the paired datasets for the River Sem target areas. 
In the River Nadder sub-catchment, the importance of the spring flows to river hydrology needs to be taken into account in any assessment of the effect of future pollution mitigation measures on river chemistry. In particular, the catchment areas of the springs (assumed to include the eastern part of the UGS outcrop at the head of the valley) should be defined, as changes to land use in these zones may have a disproportionate effect on spring, and hence river, chemistry in this part of the Hampshire Avon DTC. Given the proximity of Shaftesbury to the likely spring catchment area, possible urban effects on spring chemistry should also be considered.

For the River Ebble target sub-catchment, the effect of the rapid wetting and drying behaviour of the river on the transfer of pollutants needs to be carefully considered especially since concentrations could potentially increase in the river during the initial period of flow after a dry spell, as pollutants in the shallow subsurface are mobilised.

\subsection{Applicability of the results to other catchments}

While the above discussion shows that conceptual groundwater models are vital in helping to evaluate the effects of targeted pollution mitigation control measures in the Avon DTC and for underpinning direct comparisons of the hydrochemical data for paired sub-catchments, the general relevance of these findings to other catchments is also important and is now considered briefly.

Groundwater can provide a significant proportion of flow in the rivers of lowland Britain, with more than $90 \%$ of the rivers having baseflow indices in excess of 0.3 (Marsh and Hannaford, 2008), and much higher values being found in areas underlain by the principal aquifers. Groundwater, therefore, often forms a significant component of catchment hydraulic conceptual models.

The complexity of the groundwater flow systems observed in the Avon DTC target subcatchments is likely to be replicated elsewhere in the UK. For example, complex winterbourne behaviour is common in Chalk headwater streams, and, more generally, localised discharges in the form of springs are often a feature of catchment hydrology. Idealised groundwater systems can only occur in ideal aquifers, with attributes such as homogeneous and isotropic aquifer properties and with a large spatial extent. Where the 
geological setting is varied, such as is the case over most of the UK, then complex flow systems will result. Therefore predicting the potential effects of targeted on-farm measures in a particular part of a catchment on a receptor such as a river is likely to be highly dependent on a reliable conceptualisation of the local hydrogeological system.

Significant variability in the timescale of flow routes from the land surface to rivers is also likely to be common across the UK. In any catchment where both surface and subsurface routes are present (which, as discussed above, is likely to be the norm) a large disparity in timing between rapid surface and slow subsurface flows will occur. Within the subsurface systems, a range of flow times is likely to occur, depending on geology. For example permeable superficial deposits will promote flow which is rapid in groundwater terms, although much slower than surface runoff. Rapid subsurface flows may also occur in poorly permeable superficial deposits where agricultural land drains are present, and $40 \%$ of agricultural land across England and Wales has some form of artificial drainage. Karstic materials may likewise result in relatively rapid groundwater flows. Even within relatively homogeneous aquifers, a range of flow times will be seen, depending on the length of the flowline between recharge and discharge points. An appreciation of groundwater chemistry is necessary to ensure that river monitoring data are adequately interpreted in the context of background concentrations as well as current of future projected land use and climate scenarios.

This study has focussed on conceptual models of catchment water movement rather than accounting for geochemical processes such as nitrate attenuation in the saturated and unsaturated zones (Rivett et al. 2007, Rivett et el., 2008) or indeed nitrate removal during transit through the hyporheic zone (Krasue et al., 2009, Smith et al., 2008; Smith et al., 2009). Similarly the complexities of phosphate sources (Holman et al., 2010) and mobility (Lapworth et al., 2011; Mellander et al., 2013) have been outside the scope of this study. Although in a Chalk catchment in southern England Allen et al., (2010) found little evidence for denitrification, that is not to underplay the importance of these processes and they should not be taken into account when calculating the flux of nutrients or indeed their interaction (Lapworth et al., 2013). This is especially true where dissolved oxygen concentrations are known to be low or there is a thorough understanding of the riparian and hyporheic zones across a catchment. However, when devising catchment scale conceptual models, these 
processes need to be understood and accounted for in the monitoring strategy along with the need for collecting essential baseline physical properties data.

\section{CONCLUSIONS}

Groundwater conceptual models of the Avon DTC sub-catchments have a number of implications for the interpretation of monitoring data collected during the DTC study. Groundwater is significant in all but one of one of the target sub-catchments, and is dominant in most of them. Therefore, understanding the potential effects of mitigation measures on river chemistry must take groundwater flow routes into account. Three aspects of the groundwater contribution in particular are likely to be important:

(i) Flow systems are spatially complex: rivers in the Hampshire Avon DTC sub-catchments often do not gain flow from groundwater in a simple manner; instead, discrete inputs of water from springs are common (e.g. in the Rivers Wylye, Nadder and Sem (Cools Cottage) subcatchments). In order to understand the links between pollution mitigation measures and river chemistry it is therefore important to identify the recharge areas of significant springs.

(ii) The timescales of the various flow routes from the land surface to rivers may vary enormously. In particular, the variation in flow velocity between surface and groundwater systems may vary over orders of magnitude. Flow is likely to occur over a spectrum of timescales from rapid surface wash through slower near-surface interflow to a range of slow groundwater flow times up to decades long, depending approximately on the depth and length of the subsurface groundwater flow path. When nutrient transit through the unsaturated zone is coupled to these relatively slow flow paths, it is clear that measures put in place today are unlikely reduce nutrient concentrations in groundwaters discharging to streams by 2027 (see Wang et al., 2012). The potential for delivery of elevated nutrient concentrations over a 25year-plus time frame puts the over-ambitious aspirations of the WFD in context (Hering et al., 2010).

(iii) In the sub-catchments where groundwater contributes significantly to river discharge, the nature of baseline groundwater chemistry needs to be taken into account when considering pollutant loading; for example the potential addition of phosphate to the Upper River Wylye from natural sources in the UGS. 
In order to evaluate the effects of targeted diffuse pollution mitigation measures on rivers draining catchments it is important to understand the nature of the flow routes between the areas where the measures are applied and the point at which the effect is monitored in-river. This is particularly significant where the timescale of flow may be variable or where the flow route is uncertain, since the effectiveness of mitigation measures may be characterised incorrectly if the receiving river is monitored in the wrong place or over an inappropriate duration.

Taking the Hampshire Avon DTC as an example, groundwater is seen to be an important component of the hydrology in all but one of the DTC target sub-catchments. The groundwater conceptual models of the sub-catchments developed in this study suggest that flow routes are both spatially and temporally complex with, for example, discrete discharge areas such as springs and a variety of flow timescales. The conceptual groundwater models are seen to be essential for interpreting river monitoring data correctly.

The hydraulic characteristics of the Hampshire Avon DTC target sub-catchments are not likely to be unusual, either in the UK or elsewhere. Groundwater commonly forms a significant proportion of river flows, subsurface flow routes are often complex and rivers often receive water with a range of ages, ranging from young rapid surface runoff to very old deep groundwater input. It is therefore concluded that it is important, indeed vital, that hydrological conceptual models are employed in the evaluation and projection of the effectiveness of targeted diffuse pollution mitigation measures.

\section{ACKNOWLEDGEMENTS}

The authors thank Miss F Grant (ADAS) for helping and supporting the work, Mr I Colley (Wessex Water Plc) for information and advice and Dr C Abesser and Miss D Allen (BGS) for assistance with hydrochemical sampling and analysis. The authors would also like to thank Dr I Holman and an anonymous reviewer for their helpful comments to improve the focus of the manuscript. The work described in the paper was funded by the BGS (NERC) National Capability Programme and supported Defra project WQ0211. This paper is published with the permission of the Executive Director, British Geological Survey (NERC). 


\section{REFERENCES}

ALLEN, D.J., BREWERTON, L.J., COLEBY, L.M., GIBBS, B.R., LEWIS, M.A., MACDONALD, A.M., WAGSTAFF, S.J. \& WILLIAMS A.T. 1997. The physical properties of major aquifers in England and Wales. British Geological Survey Report WD/97/38, Environment Agency R \& D Publication 8.

ALLEN, D.J,, DARLING, W.G,, GOODDY, D.C., LAPWORTH, D.J., NEWELL. A,J., WILLIAMS, A,T, ALLEN, D. \& ABESSER C,. 2010. Interaction between groundwater, the hyporheic zone and a Chalk stream: a case study from the River Lambourn, UK. Hydrogeology Journal, 18, 5, 1125-1141.

AVON AND DORSET RIVER AUTHORITY. 1973. Upper Wylye Investigation. Avon and Dorset River Authority, Poole.

BARTON, C.M., EVANS, M., BRISTOW, C.R., FRESHNEY, C.R., \& KIRBY G.A. 1998. Reactivation of relay ramps and structural evolution of the Mere Fault and Wardour Monocline, northern Wessex Basin. Geological Magazine, 135, 383-395

BRISTOW, C.R., BARTON, C.M., WESTHEAD, R.K., FRESHNEY, E.C., COX, B.M. \& WOODS, M.A. 1999. The Wincanton district - a concise account of the geology. Memoir for 1:50 000 Geological Sheet 297. British Geological Survey.

CARPENTER, S.R., CARACO, N.F., CORRELL, D.L., HOWARTH, R.W., SHARPLEY, A.N. \& SMITH, V.H. 1998. Nonpoint pollution of surface waters with phosphorus and nitrogen. Ecological Applications, 8, 559-568.

COLLINS, A.L. \& ANTHONY, S.G. 2008. Assessing the likelihood of catchments across England and Wales meeting 'good ecological status' due to sediment contributions from agricultural sources. Environmental Science and Policy, 11, 163-170.

COLLINS, A.L., NADEN, P.S., SEAR, D.A., JONES, J.I., FOSTER, I.D.L. \& MORROW, K. 2011. Sediment targets for informing river catchment management: international experience and prospects. Hydrological Processes, 25, 2112-2129.

DARLING, W.G., BATH, A. H. \& TALBOT, J. C. 2003. The O \& H stable isotopic composition of fresh waters in the British Isles. 2. Surface waters and groundwater. Hydrology \& Earth System Sciences, 7, 183-195.

DARLING, W.G., GOODDY, D. C., MACDONALD, A. M. \& MORRIS, B. L. 2012a. The practicalities of using CFCs and SF6 for groundwater dating and tracing. Applied Geochemistry, 27, 1688-1697.

DARLING, W.G., GOODDY, D.C., MORRIS, B.L. \& PEACH, D.W. 2012b. The hydrochemistry of a Chalk aquifer during recovery from drought. Quarterly Journal of Engineering Geology and Hydrogeology, 45, 473-486. 
DRAYTON, M. 1622. Poly-Olbion. A chorographical description of all the tracts, rivers, mountains, forests and other parts of this renowned Isle of Great Britain. John Marriott, Iohn Grifmand, and Thomas Dewe, London.

GOODDY, D.C., DARLING, W.G., ABESSER, C., LAPWORTH, D.J. 2006. Using chlorofluorocarbons (CFCs) and sulphur hexafluoride (SF6) to characterise groundwater movement and residence time in a lowland Chalk catchment. Journal of Hydrology, 330, 4452.

HERING, D., BORJA, A., CARSTENSEN, J., CARVALHO, L., ELLIOT, M., FELD, C.K., HEISKANEN, A-S., JOHNSON, R.K., MOE, J., PONT, D., SOLHEIM, A.L. \& VAN DE BUND, W. 2010. The European Water Framework Directive at the age of 10: A critical review of the achievements with recommendations for the future. Science of the Total Environment, 408, 4007-4019.

HEWETT, C.J.M., QUINN, P.F., HEATHWAITE, A.L., DOYLE, A., BURKE, S., WHITEHEAD, P.G. \& LERNER, D.N. 2009. A multi-scale framework for strategic management of diffuse pollution. Environmental Modelling and Software 24, 74-85.

HOLMAN, I.P., HOWDEN, N.J.K., BELLAMY, P., WILLBY, N., WHELAN, M.J. \& RIVAS-CASADO, M. 2010. An assessment of the risk to surface water ecosystems of groundwater P in the UK and Ireland. Science of the Total Environment, 408, 1847-1857.

IAEA (INTERNATIONAL ATOMIC ENERGY AGENCY). 2006. Use of Chlorofluorocarbons in Hydrology: A Guidebook, Monograph STI/PUB/1238.

JARVIE, H.P., NEAL. C., WITHERS, P.J.A., WESCOTT, C. \& ACORNLEY, R.M. 2005. Nutrient hydrochemistry for a groundwater-dominated catchment: The Hampshire Avon, UK. Science of the Total Environment, 344, 143-158.

JOHNSON, D., FLETCHER, S.W., \& BRAY, K. 2007. Integrated assessment of nitrate concentrations for designation of groundwater nitrate vulnerable zones in England and Wales. Quarterly Journal of Engineering Geology and Hydrogeology, 40, 407-415.

KAY, D., CROWTHER, J., STAPLETON, C.M., WYER, M.D., FEWTRELL, L., ANTHONY, S., BRADFORD, M., EDWARDS, A., FRANCIS, C.A., HOPKINS, M., KAY, C., MCDONALD, A.T.,WATKINS, J. \& WILKINSON, J. 2008. Faecal indicator organism concentrations and catchment export coefficients in the UK. Water Research, 42, 2649-2661.

KRAUSE, S., JACOBS, J., VOSS, A., BRONSTERT, A. \& ZEHE, E. 2008. Assessing the impact of changes in landuse and management practices on the disuse pollution and retention of nitrate in a riparian floodplain. Science of the Total Environment 389, 149-164. 
KRAUSE, S., HEATHWAITE, L., BINLEY, A. \& KEENAN, P. 2009. Nitrate concentrations at the groundwater-surface water interface of a small Cumbrian river. Hydrological Processes, 23, 2195-2211.

LAPWORTH, D.J., GOODDY, D.C., BUTCHER, A.S. \& MORRIS, B.L. 2008 Tracing groundwater flow and sources of organic carbon in sandstone aquifers using fluorescence properties of dissolved organic matter (DOM). Applied Geochemistry, 23, 3384-3390.

LAPWORTH, D.J., GOODDY, D.C. \& JARVIE, H,P. 2011. Understanding phosphorus mobility and bioavailability in the hyporheic zone of a Chalk stream. Water Air and Soil Pollution, 218, 213-226.

LAPWORTH, D.J., GOODDY, D.C., KENT, F., HEATON, T.H.E,, COLE, S.J. \& ALLEN, D. 2013. A combined geochemical and hydrological approach to understanding macronutrient sources. Journal of Hydrology 500, 226-242.

LERNER, D.N. \& HARRIS, B. 2009. The relationship between land use and groundwater resources and quality. Land Use Policy, 26, S265-S273.

LORD, E.I., JOHNSON, P.A. \& ARCHER, J.R. 1999. Nitrate sensitive areas - a study of large-scale control of nitrate loss in England. Soil Use and Management, 15, 201-207.

MALOSZEWSKI, P. \& ZUBER, A. 1982. Determining the turnover time of groundwater systems with the aid of environmental tracers. 1, Models and their applicability. Journal of Hydrology, 57, 207-231.

MARSH, T.J. \& HANNAFORD, J. (Eds). 2008. Hydrometric Register. Hydrological data UK series. Centre for Ecology \& Hydrology, Wallingford. 210 pp.

MELlANDER, P-E., JORDAN, P, MELLAND, A.R., MURPHY, P.N.C., WALL, D.P., MECHAN, S., MEEHAN, R., KELly, C., SHINE, O. \& SHORTLE, G. 2013. Quantification of phosphorus transport from a karstic agricultural watershed to emerging spring water. Environmental Science and Technology, 47, 6111-6119.

OSTER, H. 1994. Datierung von Grundwasser mittels FCKW: Voraussetzungen, Möglichkeiten und Grenzen. PhD Dissertation, Univ. Heidelberg.

RIVETT, M.O., SMITH, J.W.N., BUSS, S.R. \& MORGAN P. 2007. Nitrate occurrence and attenuation in the major aquifers of England and Wales. Quarterly Journal of Engineering Geology and Hydrogeology, 38, 117-127.

RIVETT, M.O., BUSS, S.R., MORGAN, P., SMITH, J.W.N. \& BEMMENT, D.C. 2008. Nitrate attenuation in groundwater: A review of biogeochemical controlling processes. Water Research, 42, 4215-4232.

SILGRAM, M., WILliAMS, A., WARING, R., NEUMANN, I., HUGHES, A., MANSOUR, M. \& BESIEN, T. 2005. Effectiveness of the Nitrate Sensitive Areas Scehem in 
reducing groundwater concentrations in England. Quarterly Journal of Engineering Geology and Hydrogeology, 40, 335-352.

SMITH, J.W.N., BONELL, M., GIBERT, J., McDOWELL, W.H., SUDICKY, E.A., TURNER, J.V. \& HARRIS, R.C. Groundwater-surface water interactions, nutrient fluxes and ecological response in river corridors: Translating science into effective environmental management. Hydrological Processes, 22, 151-157.

SMITH, J.W.N., SURRIDGE, B.W.J., HAXTON, T.H. \& LERNER, D.N. 2009. Pollutant attenuation at the groundwater-surface water interface: A classification scheme and statistical analysis using national-scale nitrate data. Journal of Hydrology, 369, 392-402.

SOLEY, R.W.N., POWER, T., MORTIMORE, R.N., SHAW, P. DOTTRIDGE, J., BRYAN, B. \& COLLEY, I. 2012. Modelling the hydrogeology and managed aquifer system of the Chalk across southern England. In: SHEPLEY, M.G., WHITEMAN, M.I., HULME, P.J. \& GROUT, M.W. (eds) 2012. Groundwater Resources Modelling: A case study from the U.K. Geological Society, London, Special Publications, 364, 129-154.

TRESISE, G.R. 1960. Aspects of the Lithology of the Wessex Upper Greensand. Proceedings of the Geologists' Association, 71, 316-399.

WANG, L., STUART, M.E., BLOOMFIELD, J.P., BUTCHER, A.S., GOODDY, D.C., MCKENZIE, A.A., LEWIS, M,A. \& WILLIAMS, A.T. 2012. Prediction of the arrival of peak nitrate concentrations at the water table at the regional scale in Great Britain. Hydrological Processes. 26, 226-239

WORRALL, F., SPENCER, E. \& BURT, T.P. 2009. The effectiveness of nitrate vulnerable zones for limiting surface water nitrate concentrations. Journal of Hydrology 370, 21-28.

ZHANG, Y., COLLINS, A.L. \& GOODAY, R.D. 2012. Application of the FARMSCOPER tool for assessing agricultural diffuse pollution mitigation methods across the Hampshire Avon Demonstration Test Catchment, UK. Environmental Science and Policy 24, 120-131. 


\section{LIST OF TABLES}

Table 1. Summary of the hydrogeological properties of the geological units comprising the Avon DTC sub-catchments.

Table 2. Site locations, sample type and field measurements of unstable parameters for waters in the Wylye and Sem sub catchments.

Table 3. Major and selected trace ion data for waters in the Sem and Wylye sub-catchments.

Table 4. Stable isotope, trace gas and fluorescence data for waters in the Sem and Wylye subcatchments. Note that the $\mathrm{SF}_{6}$ analyses have been corrected for excess air inputs using the data of Gooddy et al. (2006) for Chalk groundwaters. 
Table 1. Summary of the hydrogeological properties of the geological units comprising the Avon DTC sub-catchments.

\begin{tabular}{|c|c|c|}
\hline Geological Unit & Aquifer Characteristics & $\begin{array}{l}\text { Typical hydraulic } \\
\text { conductivities }\end{array}$ \\
\hline Chalk & $\begin{array}{l}\text { Major aquifer. Fracture flow } \\
\text { dominates. Permeability tends to be } \\
\text { greatest in higher units, close to the } \\
\text { surface and in valley ottoms. }\end{array}$ & $2-192 \mathrm{~m} / \mathrm{d}$ \\
\hline Upper Greensand & $\begin{array}{l}\text { A good aquifer, particularly where } \\
\text { uncemented or where cemented units } \\
\text { are fractured. }\end{array}$ & $11-12 \mathrm{~m} / \mathrm{d}$ \\
\hline Gault Clay & Non-aquifer & \\
\hline Lower Greensand & $\begin{array}{l}\text { Commonly permeable, but too thin to } \\
\text { form a substantial aquifer }\end{array}$ & \\
\hline Portland Group & Moderate aquifer & $0.3-10 \mathrm{~m} / \mathrm{d}$ \\
\hline Kimmeridge Clay & $\begin{array}{l}\text { Non aquifer, except where there are } \\
\text { local fractured carbonate beds }\end{array}$ & \\
\hline
\end{tabular}

Table 2. Site locations, sample type and field measurements of unstable parameters for waters in the Wylye and Sem sub-catchments.

\begin{tabular}{|c|c|c|c|c|c|c|c|c|c|c|}
\hline \multicolumn{2}{|c|}{ Site No Site name } & \multirow{2}{*}{$\begin{array}{l}\text { Sub-catchment } \\
\text { Sem - Cools }\end{array}$} & \multirow{2}{*}{$\begin{array}{c}\text { Sample type } \\
\text { Spring }\end{array}$} & Location & \multirow{2}{*}{$\begin{array}{c}\begin{array}{c}\text { Temp } \\
{ }^{\circ} \mathbf{C}\end{array} \\
9.9\end{array}$} & \multirow{2}{*}{$\begin{array}{c}\begin{array}{c}\text { SEC } \\
\mu \mathrm{S} / \mathrm{cm}\end{array} \\
563\end{array}$} & \multirow{2}{*}{$\begin{array}{c}\mathbf{p H} \\
7.17\end{array}$} & \multirow{2}{*}{$\begin{array}{c}\mathbf{E h} \\
\mathbf{m V} \\
170\end{array}$} & \multirow{2}{*}{$\begin{array}{c}\text { DO } \\
\text { mg/L }\end{array}$} & \multirow{2}{*}{$\begin{array}{r}\begin{array}{r}\text { Alk } \\
\mathrm{mg} / \mathrm{L}\end{array} \\
240\end{array}$} \\
\hline 1 & Cools spring & & & Cools source spring & & & & & & \\
\hline 2 & Sem, Cools & Sem - Cools & River & Sub-catchment outlet & 18.3 & 552 & 8.17 & 176 & 8.7 & 320 \\
\hline 3 & Western BH & Wylye - west & Borehole & Marked on Figure 10 & 11.2 & 722 & 7.0 & 227 & 3.7 & 347 \\
\hline 4 & Central BH & Wylye - central & Borehole & Marked on Figure 10 & 12.1 & 598 & 7.2 & 193 & 4.6 & 311 \\
\hline 5 & Eastern BH & Wylye - east & Borehole & Marked on Figure 10 & 11.2 & 570 & 7.27 & 155 & 3.7 & 284 \\
\hline 6 & Hill Deverill spring & Wylye - east & Spring & Marked on Figure 10 & 10.1 & 558 & 7.23 & & 10.1 & 282 \\
\hline 7 & Kingston Deverill small spring & Wylye - central & Spring & Marked on Figure 10 & 10.7 & 682 & 7.08 & 186 & 9.0 & 339 \\
\hline 8 & Kingston Deverill large spring & Wylye - central & Spring & Marked on Figure 10 & 10.1 & 529 & 7.27 & 158 & 5.6 & 278 \\
\hline 9 & Kingston Deverill well & Wylye - central & Well & Marked on Figure 10 & 11.2 & 656 & 7.15 & 145 & 11.9 & 338 \\
\hline 10 & Wylye, Kingston Deverill & Wylye - central & River & Marked on Figure 10 & 12.4 & 609 & 7.44 & 148 & 8.0 & 314 \\
\hline
\end{tabular}

SEC - specific electrical conductivity

DO - dissolved oxygen

Alk - alkalinity as $\mathrm{HCO}_{3}$ 
Table 3. Major and selected trace ion data for waters in the Sem and Wylye sub-catchments.

\begin{tabular}{lccccccccccc}
\hline Site No & $\begin{array}{c}\mathbf{C a} \\
\mathbf{m g} / \mathbf{L}\end{array}$ & $\begin{array}{c}\mathbf{M g} \\
\mathbf{m g} / \mathbf{L}\end{array}$ & $\begin{array}{c}\mathbf{N a} \\
\mathbf{m g} / \mathbf{L}\end{array}$ & $\begin{array}{c}\mathbf{K} \mathbf{m} / \mathbf{L} \\
\mathbf{m g} / \mathbf{L}\end{array}$ & $\begin{array}{c}\mathbf{H C O}_{\mathbf{3}} \\
\mathbf{m g} / \mathbf{L}\end{array}$ & $\begin{array}{c}\mathbf{S O}_{\mathbf{4}} \\
\mathbf{m g} / \mathbf{L}\end{array}$ & $\begin{array}{c}\mathbf{N O}_{\mathbf{3}^{-}} \mathbf{N} \\
\mathbf{m g} / \mathbf{L}\end{array}$ & $\begin{array}{c}\mathbf{S i} \\
\mathbf{m g} / \mathbf{L}\end{array}$ & $\begin{array}{c}\mathbf{S r} \\
\mathbf{\mu g} / \mathbf{L}\end{array}$ & $\begin{array}{c}\mathbf{P}_{\text {tot }} \\
\mathbf{\mu g} / \mathbf{L}\end{array}$ \\
\hline 1 & 101 & 3.21 & 11.1 & 1.22 & 240 & 23.9 & 20.3 & 5.39 & 4.98 & 126 & 51.4 \\
2 & 95 & 10.3 & 9.3 & 1.24 & 320 & 15.5 & 24.8 & 1.98 & 4.35 & 162 & 46.5 \\
3 & 146 & 1.85 & 7.6 & 1.57 & 347 & 20.4 & 17.1 & 9.18 & 10.4 & 249 & 249 \\
4 & 120 & 1.49 & 6.6 & 1.34 & 311 & 16.2 & 16.7 & 6.37 & 10.0 & 224 & 80.0 \\
5 & 112 & 1.55 & 6.2 & 1.29 & 284 & 14.0 & 19.3 & 5.96 & 12.5 & 248 & 115 \\
6 & 110 & 1.19 & 5.7 & 0.86 & 282 & 13.9 & 13.9 & 8.58 & 5.73 & 204 & 31.2 \\
7 & 139 & 1.69 & 7.4 & 2.46 & 339 & 17.3 & 16.2 & 7.63 & 10.2 & 248 & 301 \\
8 & 112 & 1.22 & 5.8 & 1.28 & 278 & 14.1 & 14.2 & 9.22 & 4.43 & 190 & 20.6 \\
9 & 133 & 1.45 & 6.2 & 1.26 & 338 & 13.5 & 12.9 & 9.59 & 4.58 & 229 & 96.0 \\
10 & 122 & 1.40 & 6.1 & 2.22 & 314 & 15.9 & 15.5 & 8.24 & 6.96 & 217 & 75.0 \\
\hline
\end{tabular}

Table 4. Stable isotope, trace gas and fluorescence data for waters in the Sem and Wylye subcatchments. Note that the $\mathrm{SF}_{6}$ analyses have been corrected for excess air inputs using the data of Gooddy et al. (2006) for Chalk groundwaters.

\begin{tabular}{|c|c|c|c|c|c|c|c|c|}
\hline \multirow[t]{2}{*}{$\overline{\text { Site No }}$} & $\delta^{18} \mathrm{O}$ & $\delta^{2} H$ & \multicolumn{2}{|c|}{$\delta^{13}$ C-DIC CFC-11 } & \multirow{2}{*}{$\begin{array}{l}\text { CFC-12 } \\
\mathrm{pmol} / \mathrm{L}\end{array}$} & \multirow{2}{*}{$\begin{array}{c}\text { SF6 }_{c} \\
\text { fmol/L }\end{array}$} & \multicolumn{2}{|c|}{ 'Fulvic-like' 'Tryptophan-like' } \\
\hline & \multicolumn{2}{|c|}{ \% VSMOW } & $\%$ PDB & $\mathrm{pmol} / \mathrm{L}$ & & & a.u. & a.u. \\
\hline 1 & -6.80 & -41.1 & -16.9 & 8.18 & 2.06 & 1.73 & & \\
\hline 2 & -6.47 & -40.8 & & & & & & \\
\hline 3 & -6.45 & -41.1 & -18.1 & 8.31 & 3.50 & 1.84 & 5.302 & 3.095 \\
\hline 4 & -6.43 & -40.5 & -16.6 & 8.34 & 2.08 & 1.44 & 2.798 & 2.570 \\
\hline 5 & -6.72 & -42.5 & -15.6 & 5.80 & 2.29 & 1.13 & 3.097 & 2.875 \\
\hline 6 & -6.62 & -42.9 & -13.5 & 9.19 & 2.74 & 1.55 & 3.175 & 2.180 \\
\hline 7 & -6.87 & -43.5 & -17.5 & & & & 5.541 & 3.391 \\
\hline 8 & -6.73 & -42.5 & -15.9 & 7.94 & 2.27 & 1.08 & 0.349 & 0.104 \\
\hline 9 & -6.36 & -41.7 & -15.5 & 7.64 & 3.38 & 1.22 & 4.316 & 3.093 \\
\hline 10 & -6.52 & -43.7 & & & & & 6.106 & 4.345 \\
\hline
\end{tabular}




\section{LIST OF FIGURES}

Figure 1. Geological setting of the sub-catchments and their location in southern England

Figure 2. Topography of the Wylye sub-catchment.

Figure 3. Bedrock geology of the Wylye sub-catchment.

Figure 4. Bedrock geology of the Cools Cottage sub-catchment.

Figure 5. Bedrock geology of the Sem Priors Farm sub-catchment.

Figure 6. Bedrock geology of the Nadder sub-catchment.

Figure 7. Bedrock geology of the Ebble sub-catchment.

Figure 8. Schematic section through the Upper Greensand (UGS) aquifer below the Upper Wylye sub-catchment (approximate line of section shown in Figure 3).

Figure 9. Schematic section showing the Chalk aquifer below the Upper Wylye subcatchment (approximate line of section shown in Figure 3).

Figure 10. Sampling points in the Upper Wylye sub-catchment related to geology. Red dots springs, purple dots - boreholes, blue dot - river.

Figure 11. Plot of $\mathrm{Si}$ concentration versus $\mathrm{Mg} / \mathrm{Ca}$ ratio, showing mixing between Chalk baseline (Sites 6,8,9) and Upper Greensand (Site 5) groundwaters. Site location information in Table 2 and Figure 10.

Figure 12. Plot of CFC-12 versus $\mathrm{SF}_{6}$ concentration for selected samples (site numbers in bold). Also shown are the curves for various 'lumped parameter' flow models (Maloszewski, and Zuber, 1982). PFM - piston flow model, EPM - exponential piston flow model, EMM exponential mixing model. Curves show the mean residence time in years, and are based on atmospheric mixing ratios (http://water.usgs.gov/lab/software/air_curve/) and the assumption of a $10^{\circ} \mathrm{C}$ recharge temperature.

Figure 13. Schematic section showing the Chalk aquifer below the Upper Wylye subcatchment with age information added. The Central BH (Table 2, Figure 10) is screened in 
both the UGS and Chalk, with its mean residence time (MRT) of $25 \mathrm{yrs}$ implying that the age of water in the confined UGS is older. However, the artesian Eastern BH, screened only in the UGS, yields a similar MRT and therefore may be affected by lateral inflow of younger water.

Figure 14. Plot of $\mathrm{NO}_{3}-\mathrm{N}$ versus $\mathrm{P}$ concentration, showing a mixing line between relatively high-N and low-P Chalk water, and high-P lower-N water from the Upper Greensand. Some sites, notably 3 and 7, are affected by additional inputs of phosphorus derived from agriculture.

Figure 15. Schematic diagram showing the principal hydrogeological functioning of the Sem Cools Cottage sub-catchment (approximately along the section line shown in Figure 4). Dashed lines show possible potentiometric surfaces.

Figure 16. Schematic diagram showing the principal hydrogeological features of the Nadder sub-catchment (line of section is approximately that shown in Figure 6).

Figure 17. Schematic diagram showing the principal hydrogeological features of the Ebble sub-catchment (approximately along the section line shown in Figure 7).

Figure 18. Schematic diagram showing the relative location of DTC monitoring cabinets (red dots) and augmentation boreholes (arrows) in the Upper Wylye sub-catchment (approximately along the section line shown in Figure 3). 


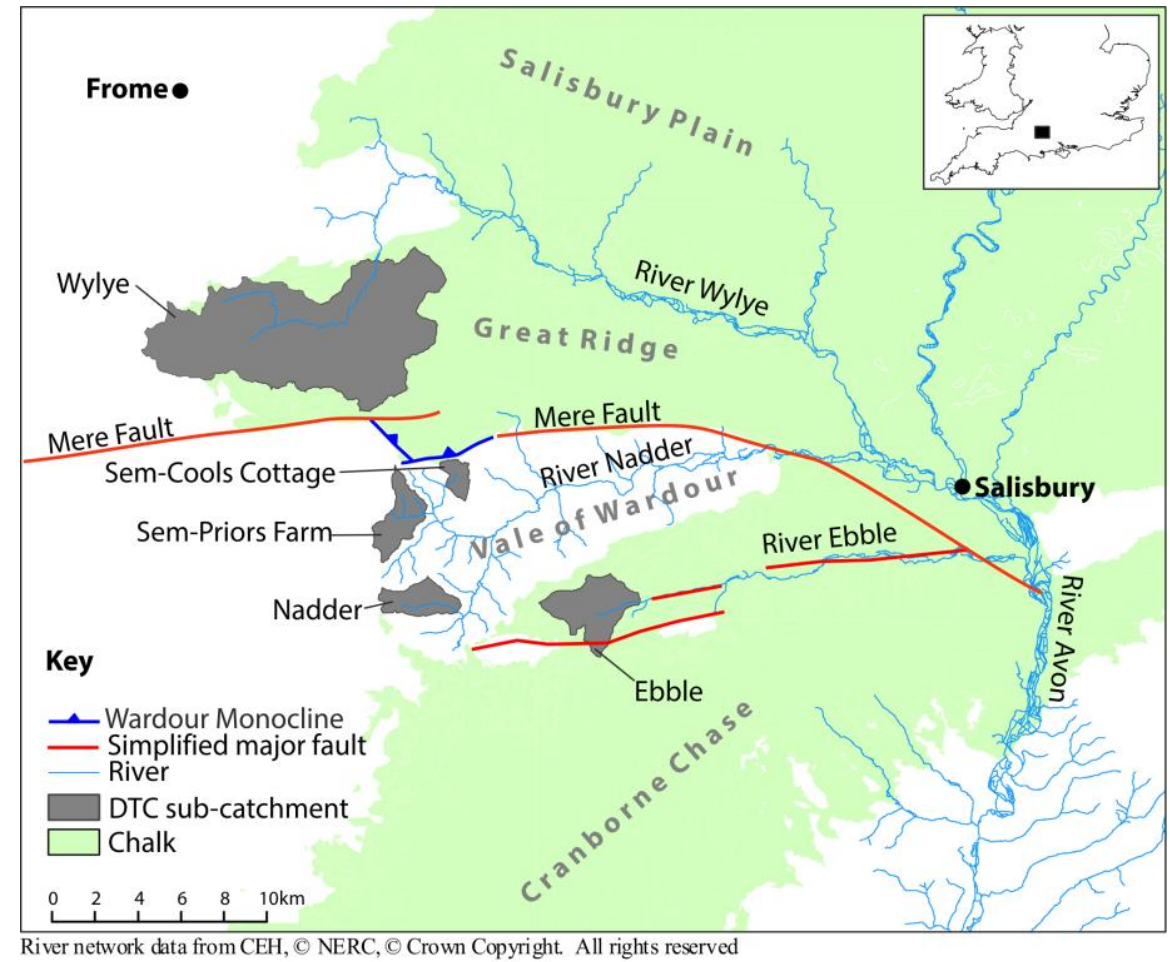

\section{Figure 1}

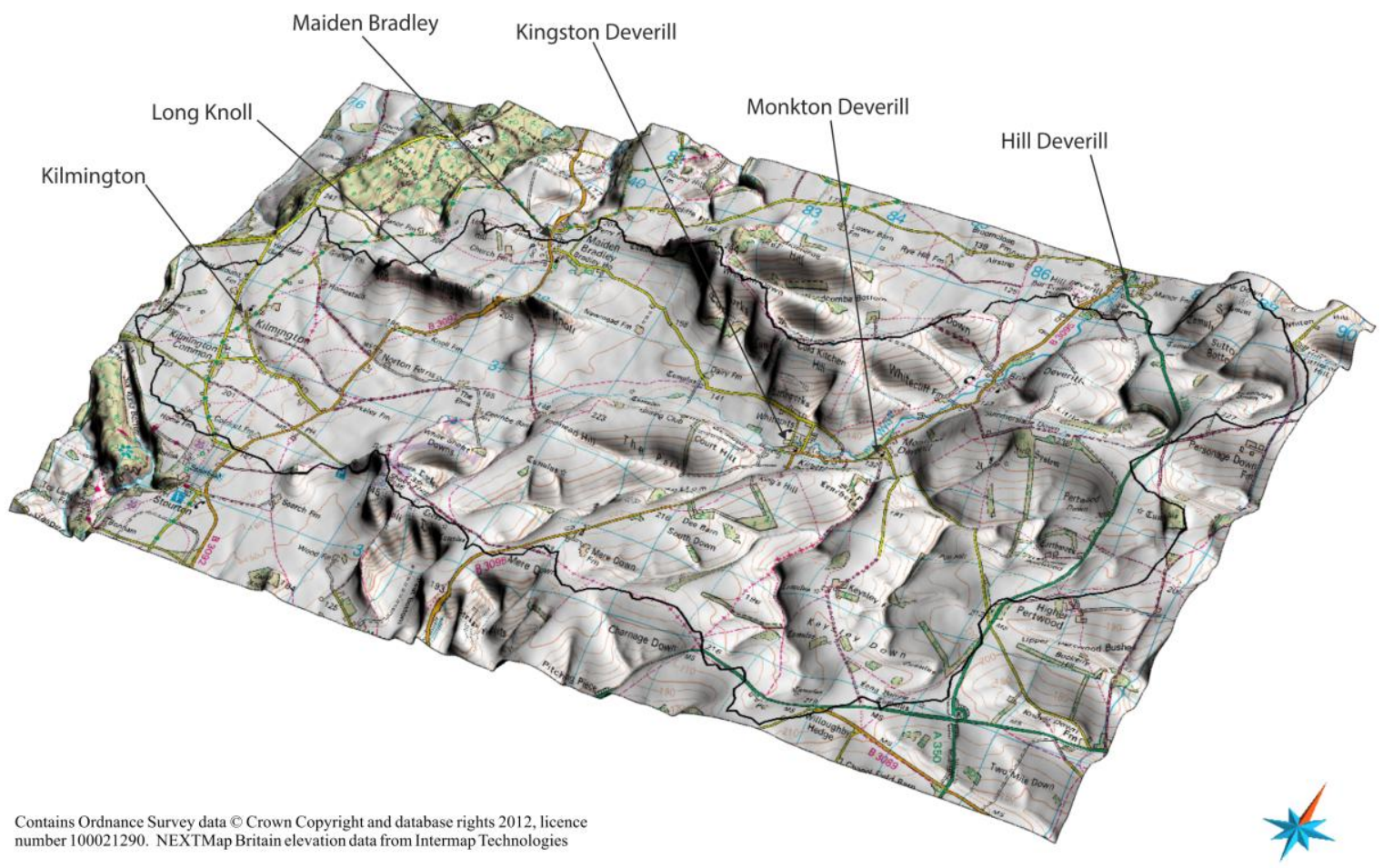

Figure 2 


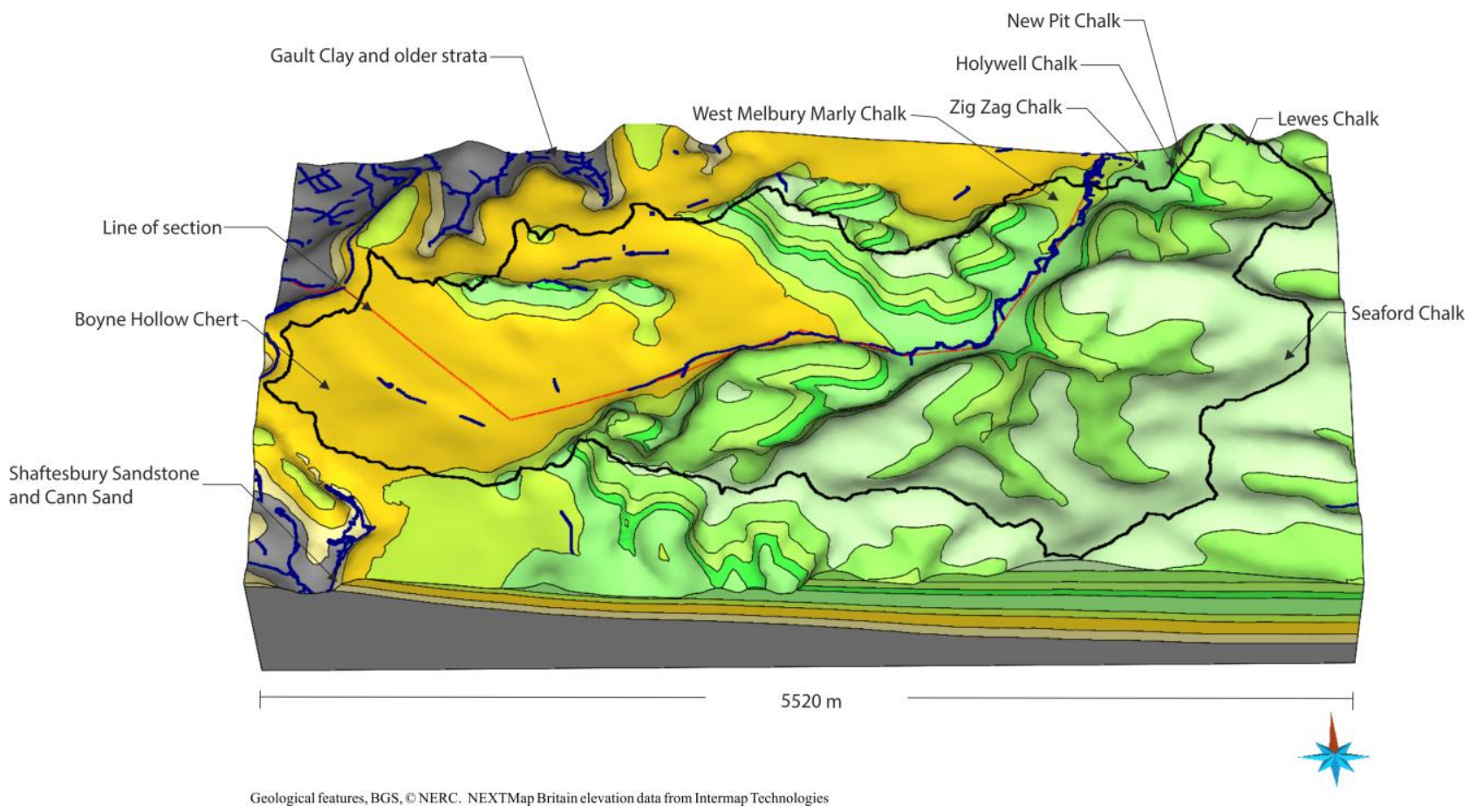

Figure 3

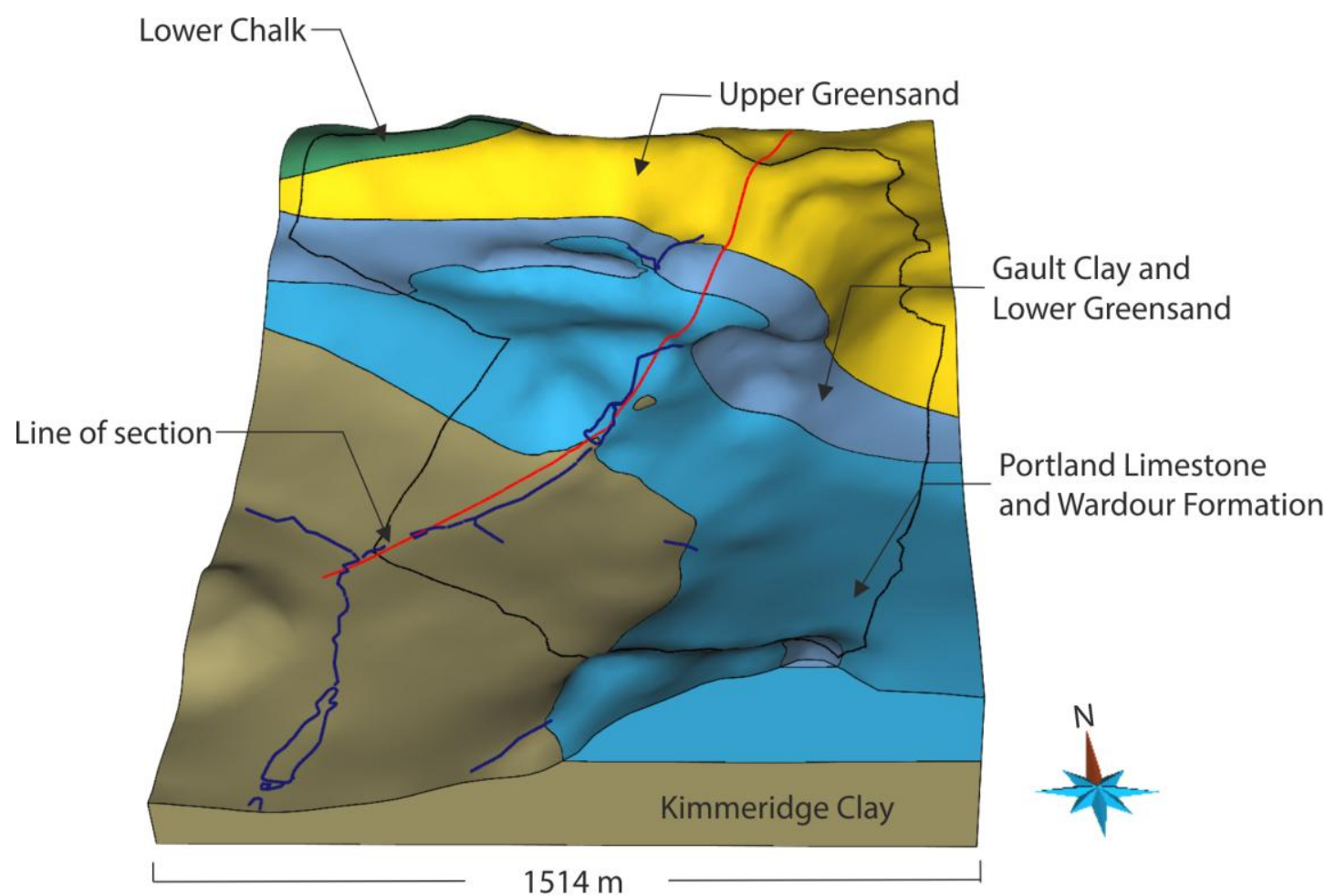

Geological features, BGS, (C NERC. NEXTMap Britain elevation data from Intermap Technologies

Figure 4 


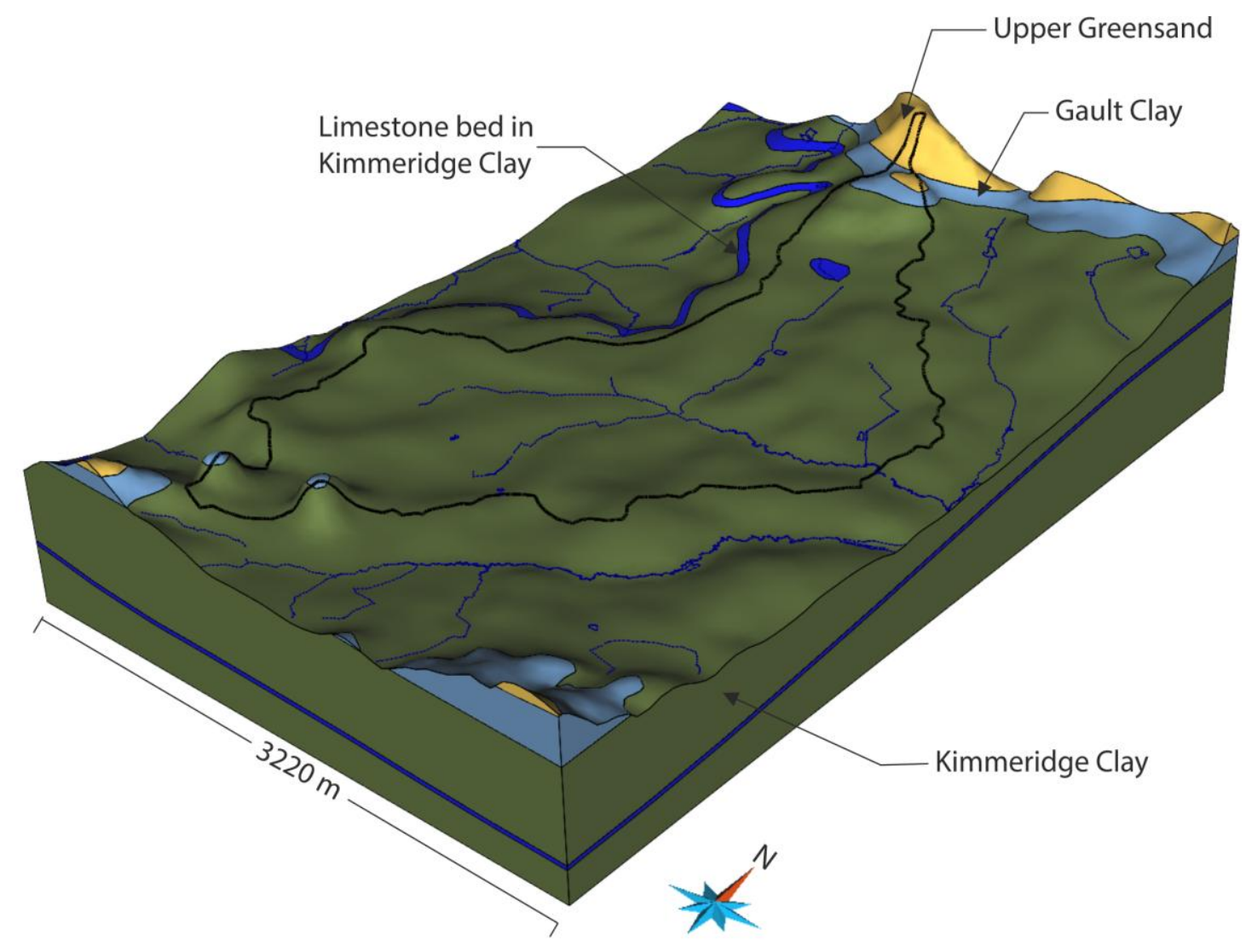

Geological features, BGS, C NERC. NEXTMap Britain elevation data from Intermap Technologies

\section{Figure 5}

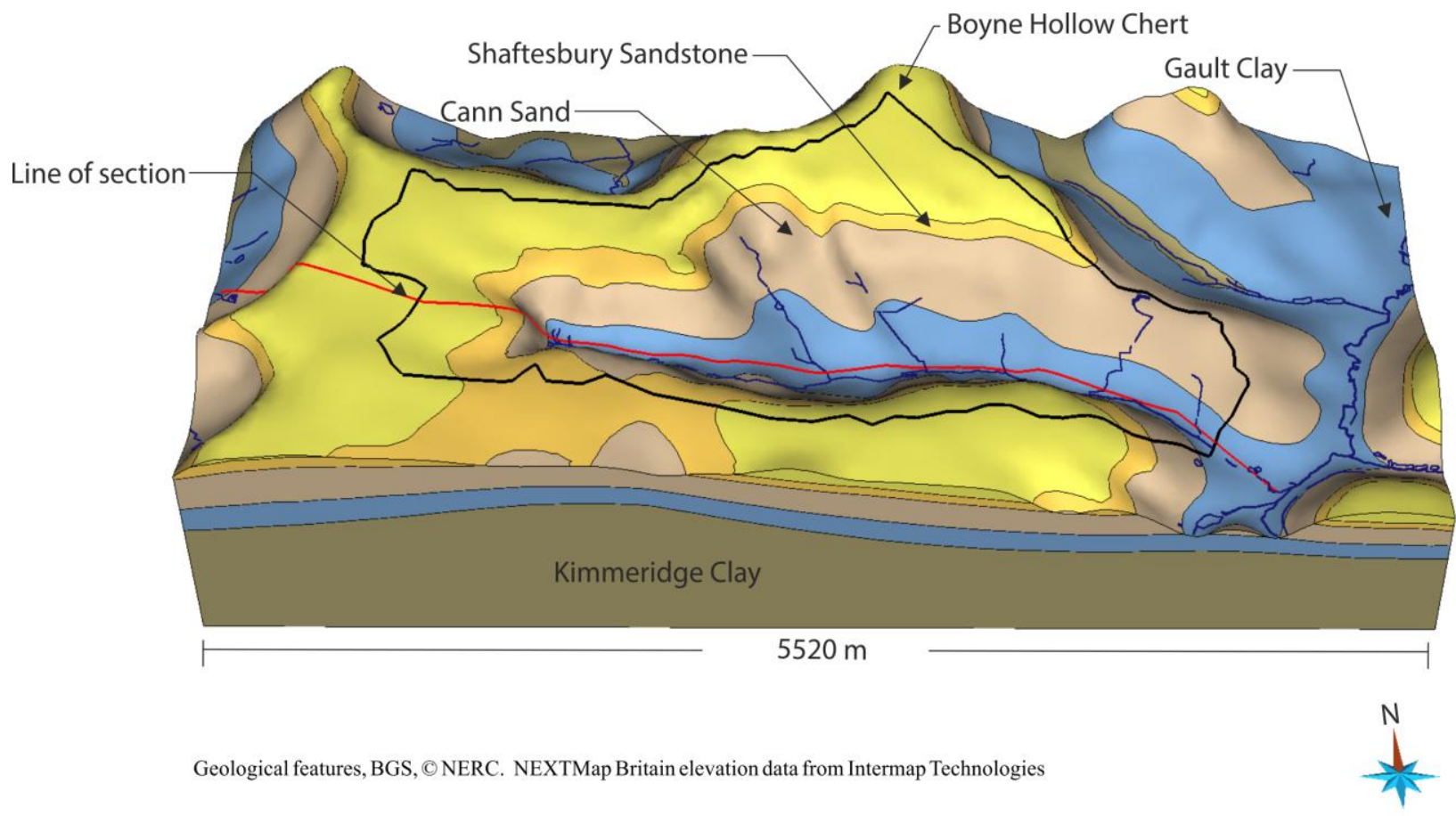

\section{Figure 6}




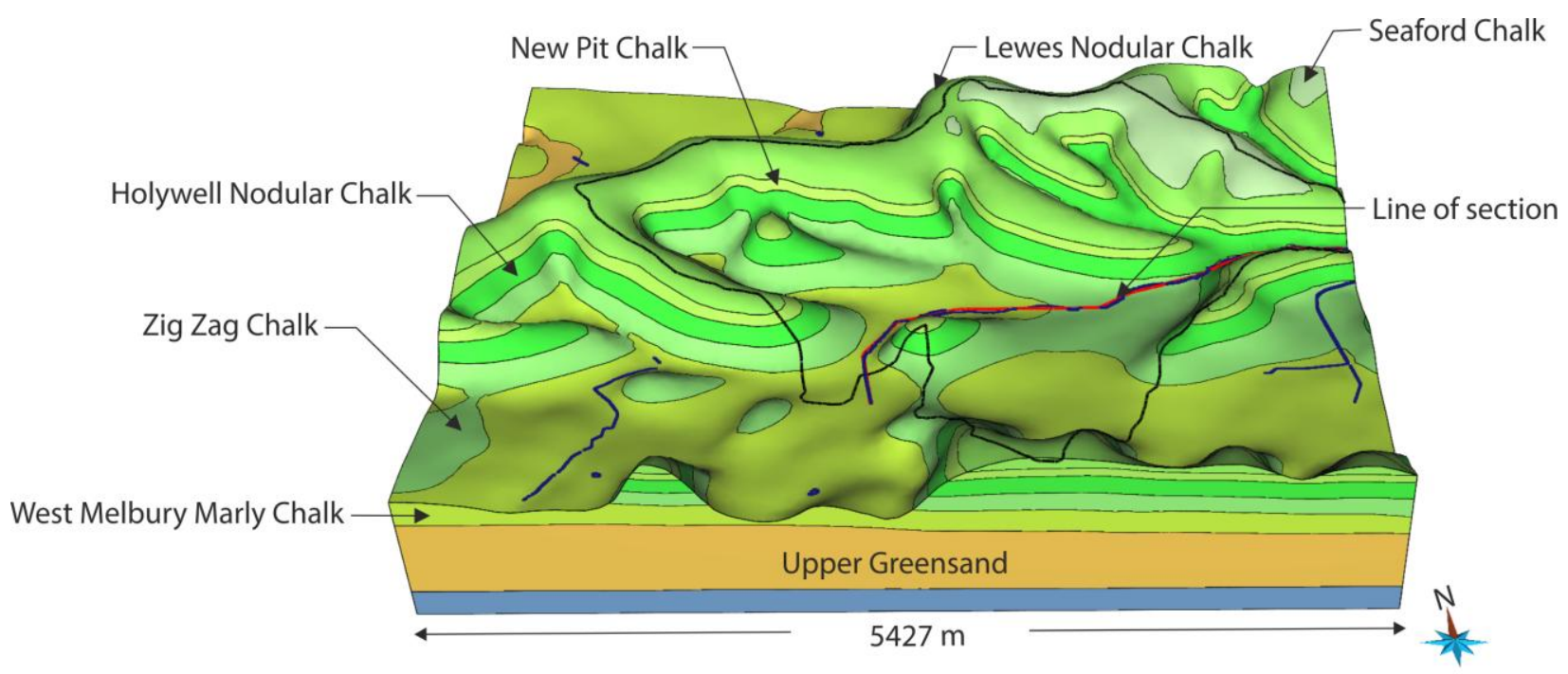

Geological features, BGS, C NERC. NEXTMap Britain elevation data from Intermap Technologies

\section{Figure 7}

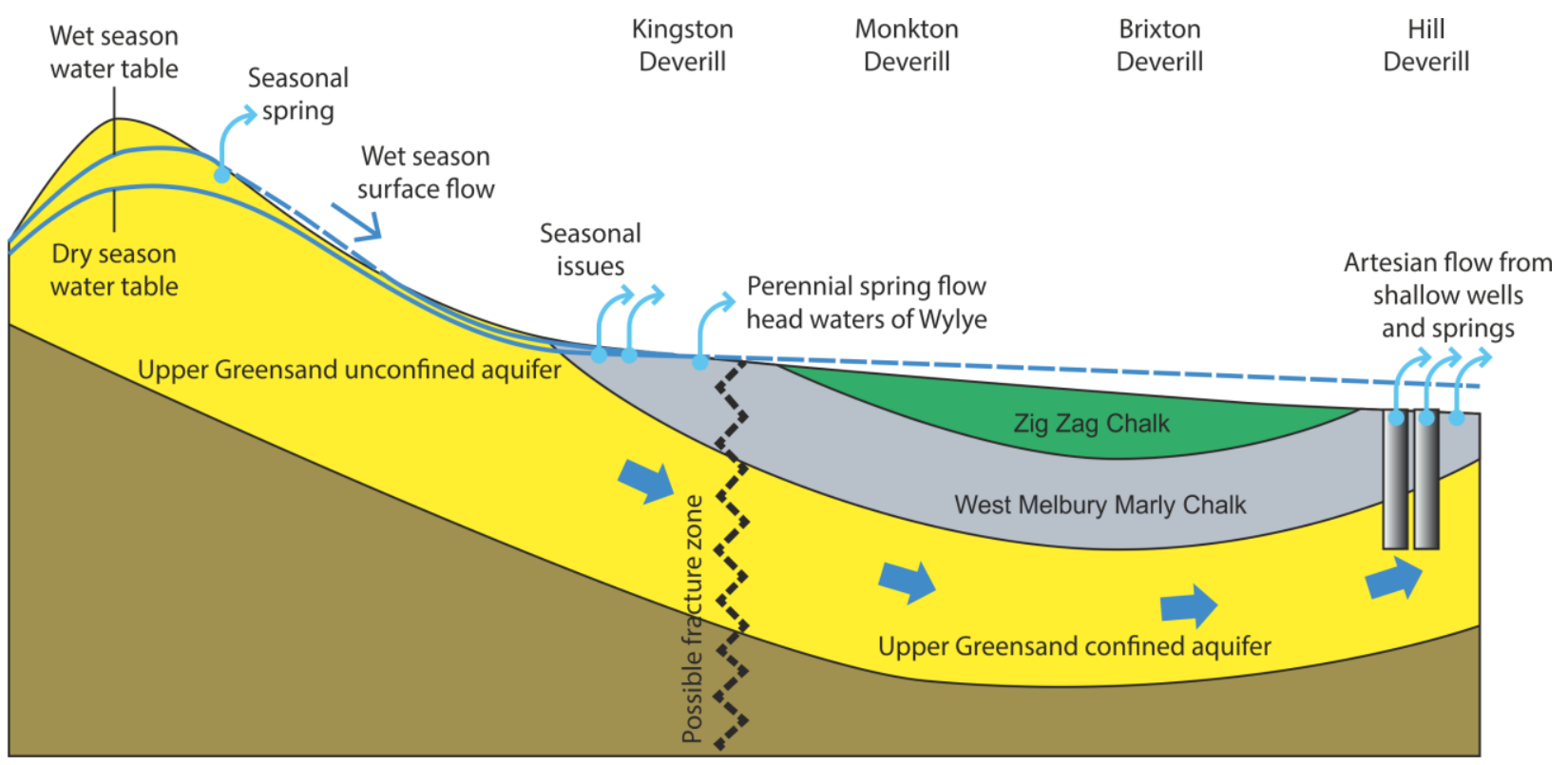

\section{Figure 8}




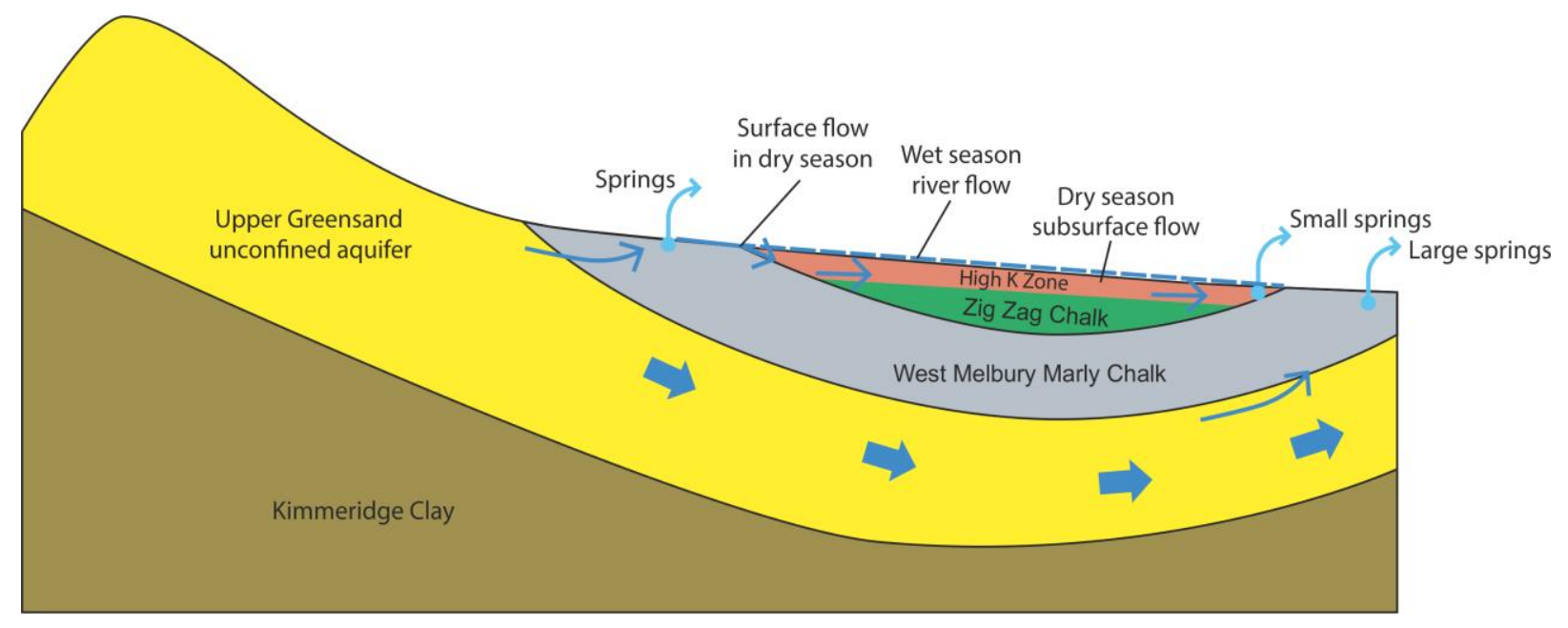

\section{Figure 9}

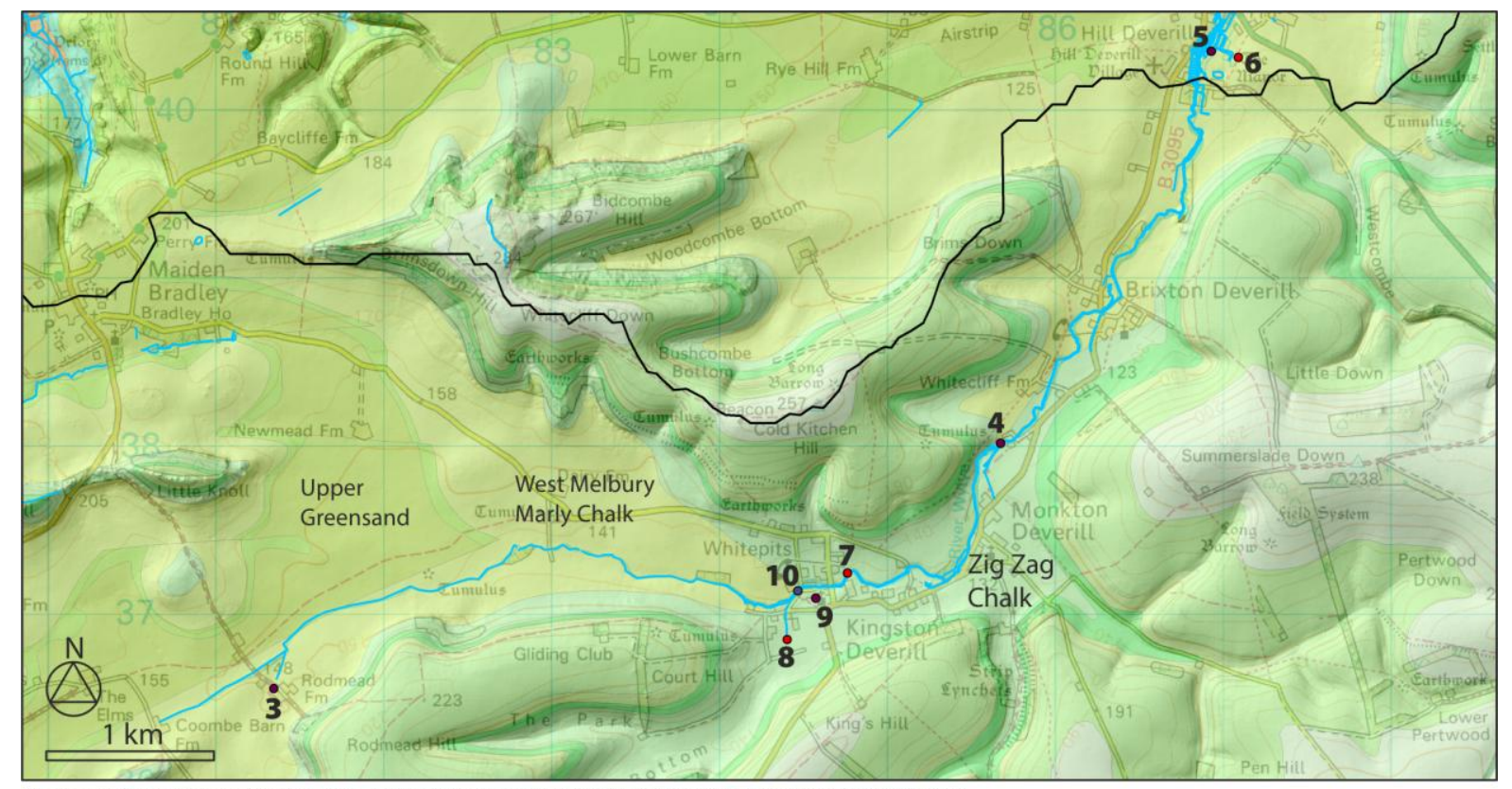

Geological features, BGS, ( $)$ NERC. NEXTMap Britain elevation data from Intermap Technologies

\section{Figure 10}




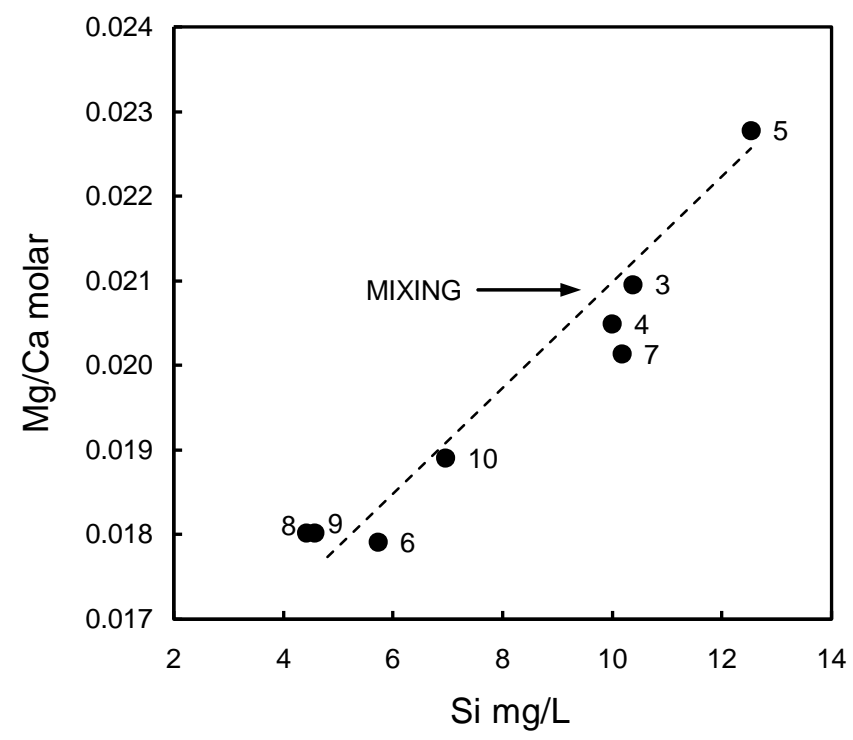

Figure 11

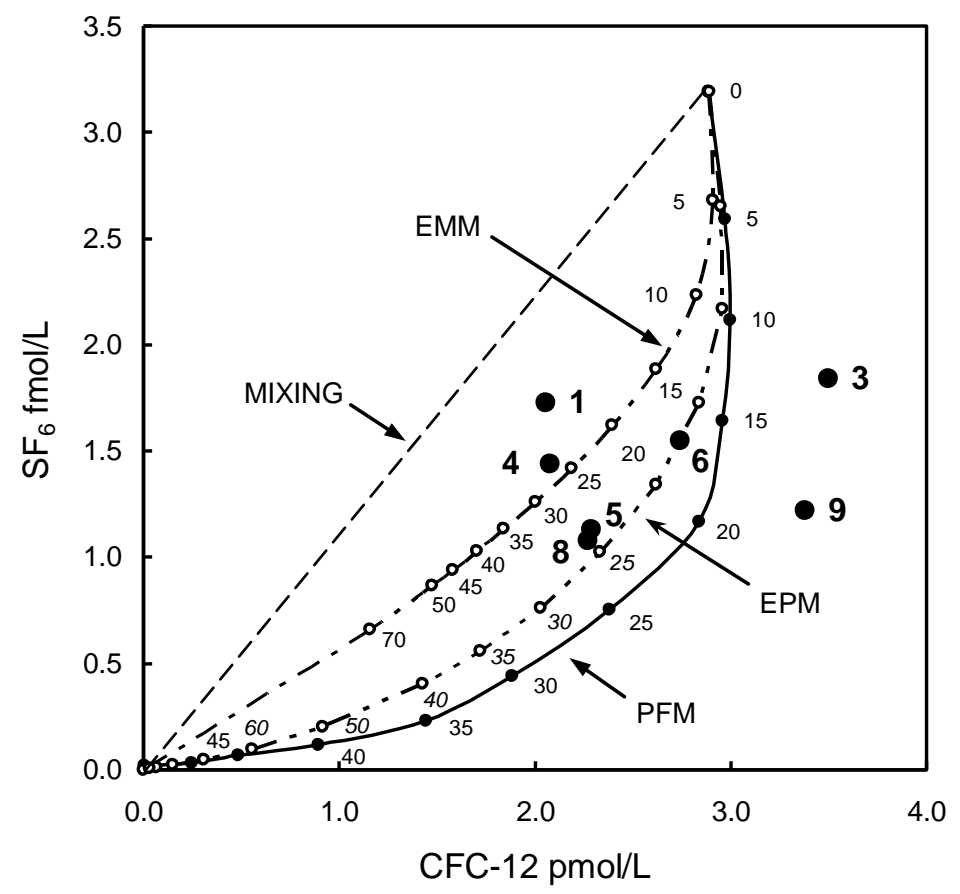

Figure 12 


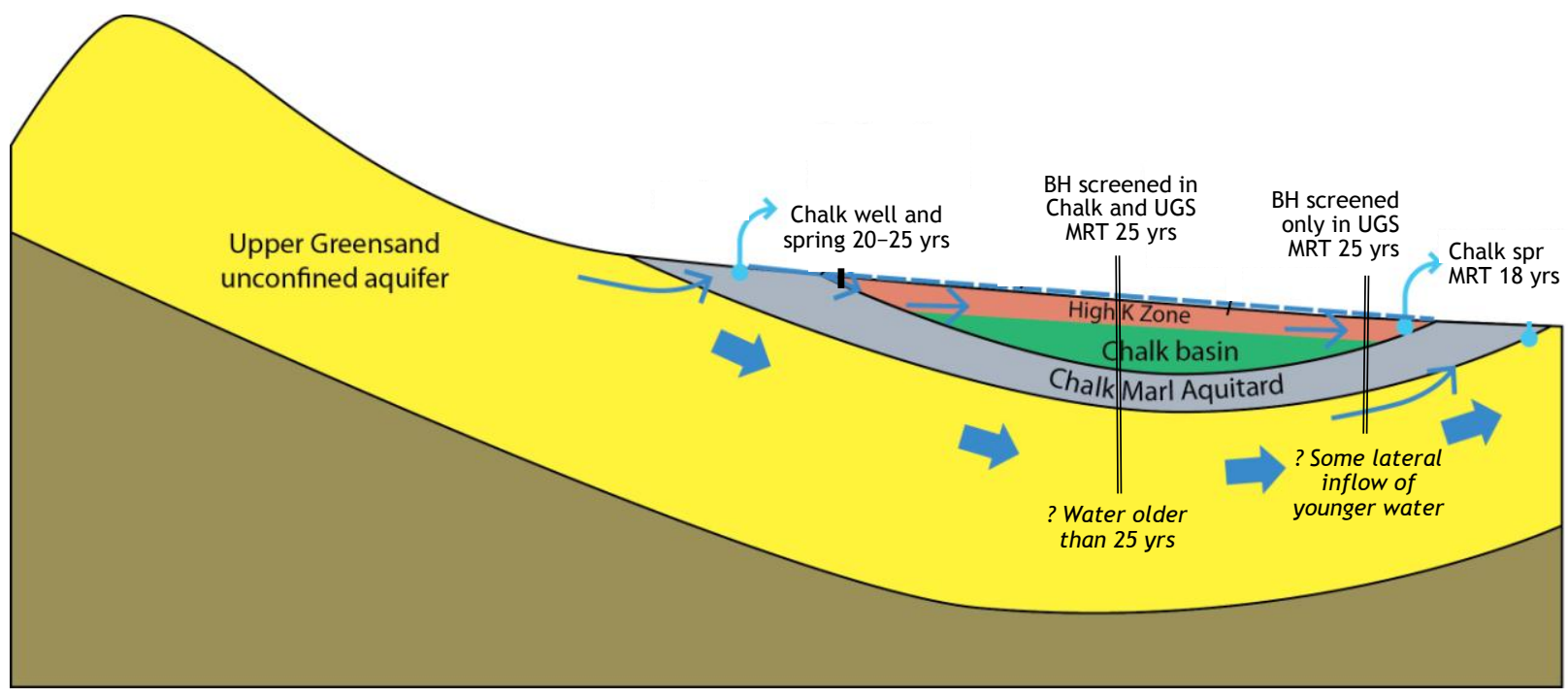

\section{Figure 13}

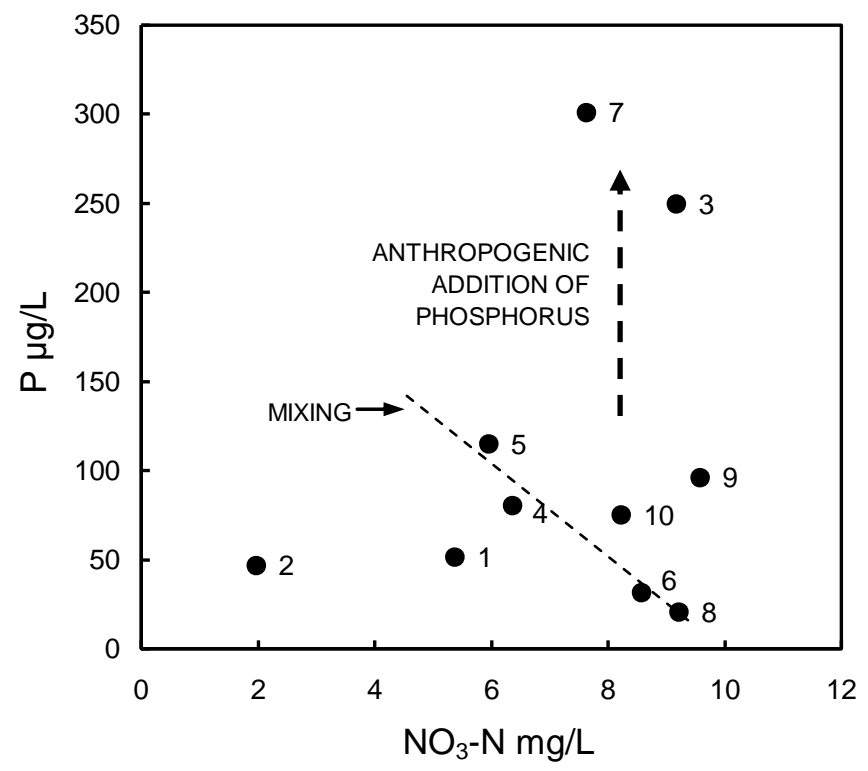

Figure 14 


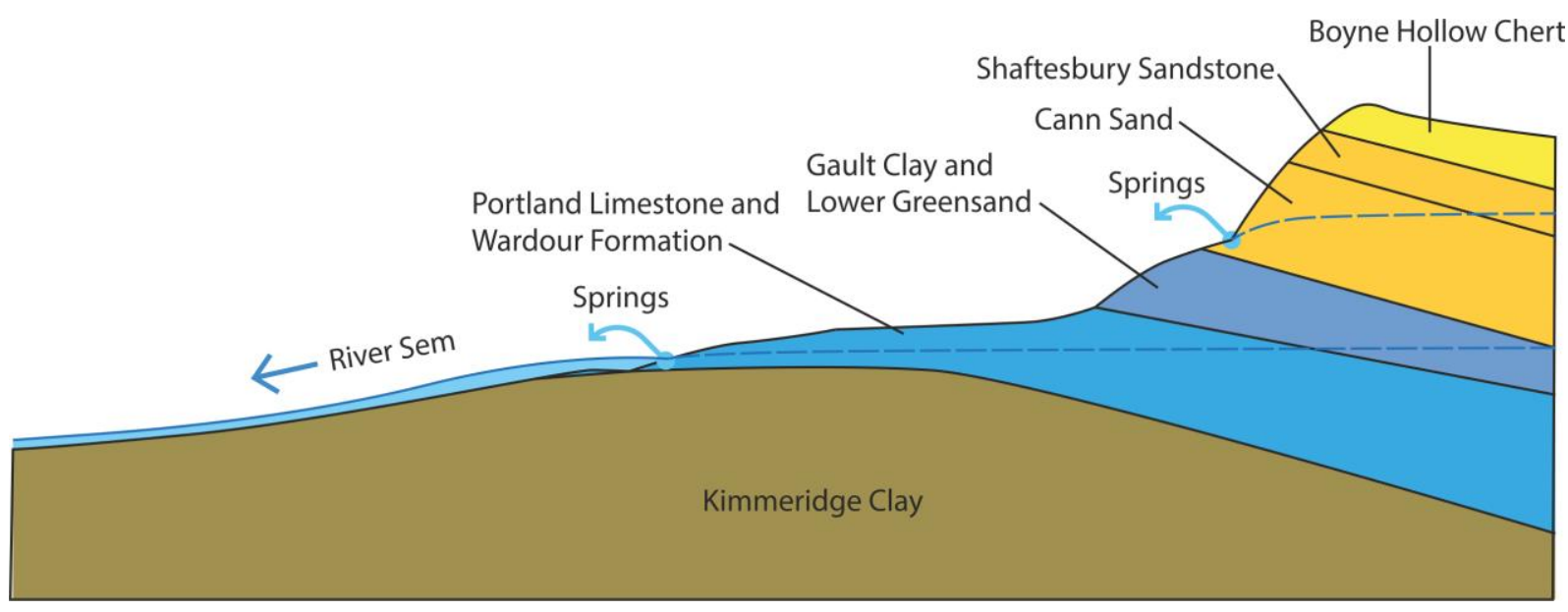

\section{Figure 15}

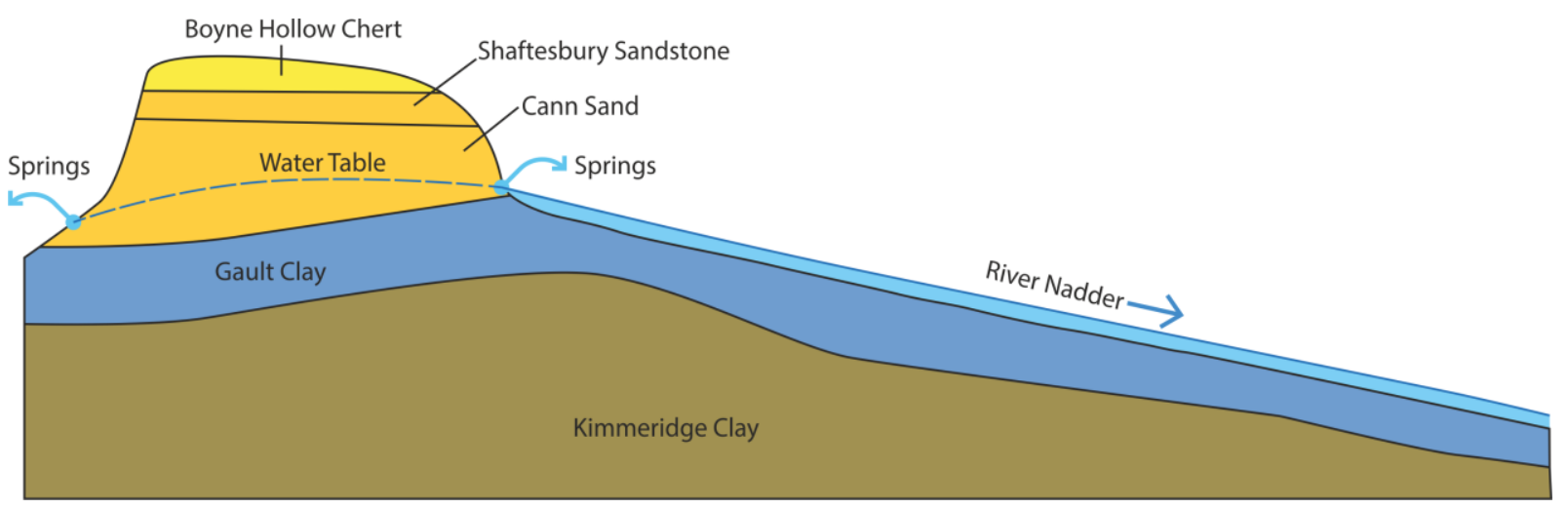

Figure 16 


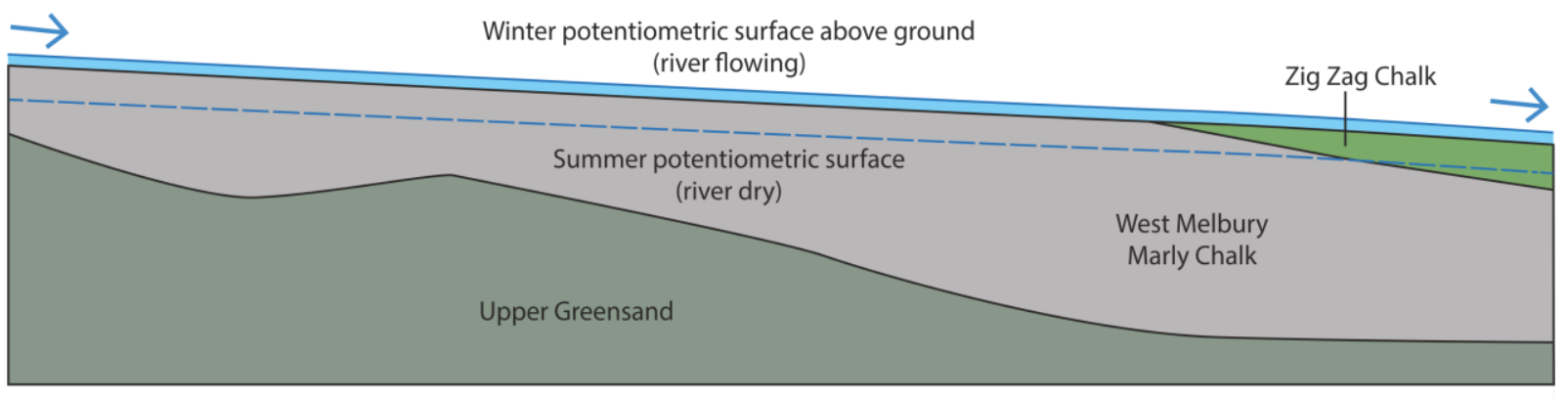

Figure 17

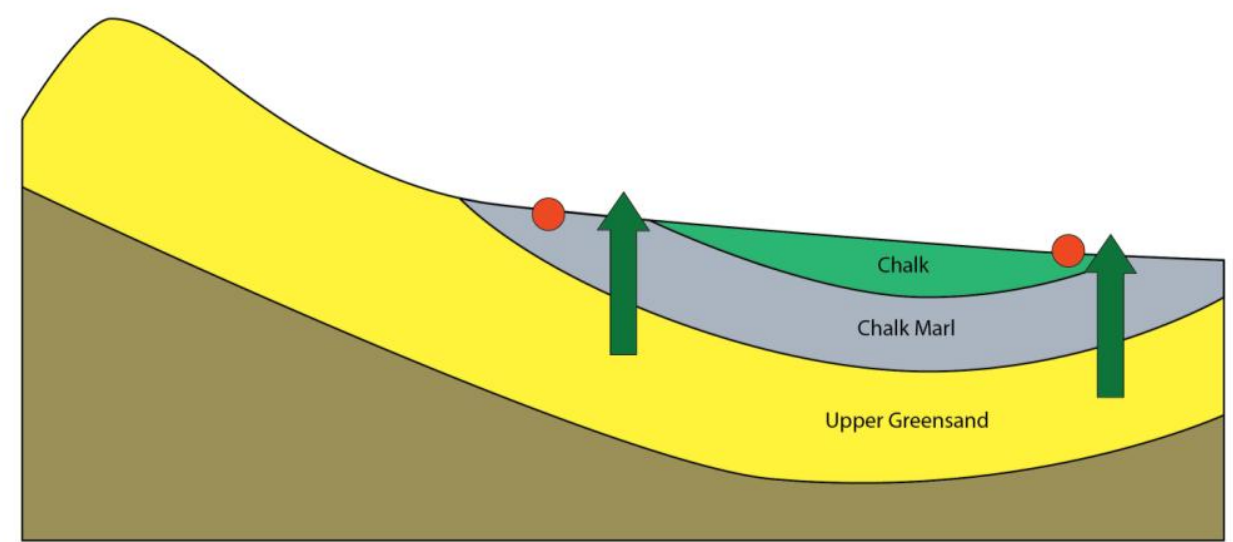

Figure 18 